\title{
ARTHUR SCHOPENHAUER'IN HUKUK VE CEZA ADALETİ ANLAYIŞI
}

\author{
ARTHUR SCHOPENHAUER'S LAW AND CRIMINAL-JUSTICE IDEAS
}

\author{
Pirali Çağrı ŞENSOY***
}

Makale Bilgi

Gönderi: 26/01/2021

Kabul : 12/04/2021

\section{Anahtar Kelimeler}

Arthur Schopenhauer, Hukuk Felsefesi,

Ebedi-Adalet ve

Zamansal-Adalet,

Devletin Kökeni,

Cezalarin Amaci.

\section{Article Info}

Received: 26/01/2021

Accepted: 12/04/2021

\section{Keywords}

Arthur Schopenhauer,

Philosophy of Law,

Eternal Justice and

Temporal Justice,

Origin of the State,

Purpose of Punishments.
Özet

https://dai.org/l0.21492/inuhfd.868992 do

Arthur Schopenhauer pek çok düşünüre ve felsefî ekole ilham kaynağı olmuş önemli bir filozoftur. Schopenhauer'ın felsefî fikirleri üzerine bugüne kadar çok sayıda tez çalışması yapılmış, pek çok eseri Türkçeye tercüme edilmiştir. Filozofun hayatın her alanına temas eden dünya görüşü, hukuk felsefesi alanında da fikirler ortaya koymasına imkân sağlamıştır. $\mathrm{Bu}$ çalışma, Schopenhauer'ın hukuk felsefesine dair görüşlerini inceleyerek filozofu Türkçe literatüre tanıtmayı amaçlamaktadır. Çalışmamıza göre; Schopenhauer, hak kavramını doğal hukukçu olarak anılabilecek bir yaklaşımla ele almaktadır. Adalet kavramını kapsamlı bir şekilde inceleyen Schopenhauer, "ebedî adalet" ve "zamansal-adalet" tanımlamaları ve analizleri üzerinden düalist bir perspektif geliştirmektedir. Devletin kökenini "sosyal sözleşme" ile açıklayan Schopenhauer, devleti bir "koruma kurumu" olarak tanımlamaktadır. Filozofun fikirlerinde zamansal-adaletin gereği olan cezalar önemli bir yer tutmaktadır. Cezaların "caydırıcıllk" amacına hizmet etmesi gerektiği üzerinde duran Schopenhauer, "hücre hapsi" ve "tecrit" gibi mühim kavramlara yönelik önemli tartışmalar geliştirmektedir. Çalışmamızda Türk doktrininin Schopenhauer'ın yaklaşımından yararlanarak günümüz tartışmalarına farklı bir bakış açısıyla yaklaşabileceği tartışılmaktadır.

Abstract

Arthur Schopenhauer, a well-known western philosopher, has inspired numerous scholars and philosophical schools. Various academic dissertations have scrutinised Schopenhauer's ideas and some of his works have been translated into Turkish. Schopenhauer's world-view, which touches upon all aspects of life, has enabled him to come up with ideas in the field of philosophy of law. This article seeks to introduce the philosopher to the Turkish literature by examining Schopenhauer's views on the philosophy of law. According to the article, Schopenhauer embraces a natural-law approach in dealing with the concept of right. He examines the concept of justice in a comprehensive manner and develops a dualist perspective via his definitions and analysis of "eternal justice" and "temporal justice". Schopenhauer defines the state as an "institution of protection" when explaining the origin of the state through the so-called "social contract". He takes into account punishments that are recognised as the requirement for temporal justice. He develops many discussions on some important concepts such as "solitary confinement" and "isolation" while emphasising that punishments should serve the purpose of "deterrence". Whilst analysing Schopenhauer's standpoints on all aforementioned concepts, this article explains how his ideas would contribute to the Turkish doctrine.

\footnotetext{
*Arş. Gör., Recep Tayyip Erdoğan Üniversitesi, Hukuk Fakültesi, Hukuk Felsefesi ve Sosyolojisi Anabilim Dall.

** Yoğun çalışma temposunda bana ve makaleme zaman ayıran Sn. Dr. Öğr. Üyesi Hakan KOLÇAK'a ve çalışmalarımda yol gösterici olması adına kendi çalışmalarını benimle paylaşan Sn. Doktorant Murat KAYMAZ'a katkılarından dolayı teşekkür ederim.
} 


\section{GİRIŞ}

Arthur Schopenhauer Kant sonrası felsefenin önemli filozoflarından birisidir. Schopenhauer; Nietzsche, Wittgenstein, Heidegger, Sartre gibi önemli filozoflara; yine Freud, Jung gibi psikolojinin kurucularına; Tolstoy, Emile Zola, Çehov gibi edebiyatçılara; Wagner gibi sanatçılara, Einstein gibi bilim insanlarına, başta varoluş̧̧u felsefe olmak üzere pek çok felsefî ekole ve farklı disiplinlerdeki düşünürlere ilham kaynağ 1 olmuştur ${ }^{1}$. Bunun yanında Marx ve Gandhi gibi isimlerin de Schopenhauer'ın fikirlerinden etkilendiği ifade edilmektedir². Ülkemizde de çokça Schopenhauer araştırması yapılmış, yazılan tezler ve makalelerin yanında Schopenhauer'a ait pek çok eser dilimize tercüme edilmiştir ${ }^{3}$. Özellikle insan psikolojisine ışık tutan yaklaşımıyla Schopenhauer ülkemiz felsefe çevrelerinde yankı uyandırdığı gibi akademi dışındaki felsefe meraklıları arasında da belirli bir popülerliğe sahiptir.

Çalışmamızda Schopenhauer'ın hukuk felsefesinin belirli kavramlarını ele alış biçimi ceza adaletine ilişkin görüşleriyle bir araya getirilerek Türkçe hukuk literatürüne kazandırılması hedeflenmiştir. Bu amaçla öncelikle filozofun temel kitapları incelenmiştir. Filozofun temel eseri olan Die Welt als Wille und Vorstellung (Isteme ve Tasarm Olarak Dünya / The World as Will and Representation) iki ciltlik bir eserdir. Bu eser Türkçeye kısaltılarak tercüme edilmiştir ${ }^{4}$. Biz bu kısaltmaları göz önünde bulundurarak çalışmamızda eserin Türkçe tercümesiyle İngilizce tercümesini karşılaştırmalı olarak kullanmayı tercih ettik. Yine filozofun mühim eserlerinden biri olan ve Türkçeye tercüme edilmemiş olan "Die Beiden Grundprobleme der Ethik" (the Two Fundamental Problems of Ethics / Ahlakın Íki Temel Sorunu) kitabını İngilizce tercümesinden inceledik. Filozofun eserlerinden Türkçeye kazandırılmış olan yirmi eseri tarad $1 k^{5}$, konumuz açısından önemli olarak gördüğümüz noktalarda bu eserlerden faydalandık. Ek olarak, Ulusal Tez Merkezi'nde yer alan yerli kaynaklarımızın tamamını tarayıp çalışmamızla ilişkilendirilebilecek tezlerden ve pek çok monografik çalışmadan yararlandık ${ }^{6}$. Bununla birlikte Alman filozof Schopenhauer'a yönelik esaslı bir çalışmanın Almanca literatürün taranmasıyla mümkün olabileceğini araştırmamız sürecinde keşfettik. Araştırmacının Almancayı henüz bilmiyor olması çalışmanın bir zayıf yönü olarak değerlendirilebilir.

Çalışmamızda Schopenhauer'ın genel felsefesi derinlemesine analiz edilmek yerine hukuk ve ceza adaletiyle ilgili yaklaşımları Türkçe hukuk literatürüne katkı sunması amacıyla irdelenecektir. Hak ve adalet kavramlarını özgün bir şekilde ele alan filozofun devlet ve ceza adaleti yaklaşımı günümüz hukuki problemlerini farklı bir gözle değerlendirmeye imkân sağlayabilir. Buna göre çalışmada Schopenhauer'ın görüşleri hukuk felsefesi ile ceza adaleti başlıkları altında sınıflandırılarak betimlenecektir.

Çalışmamız iki ana bölümden oluşacaktır. İlk bölümünde Schopenhauer'ın fikirlerine kaynaklık eden İmmanuel Kant'ın fikirleri özetlenerek Schopenhauer'ın varlık felsefesi ve ahlak felsefesi fikirleri tanıtılacaktır. İkinci bölümünde ise Schopenhauer'ın hukuk felsefesi kapsamlı bir şekilde incelenecek ve yorumlanacaktır. Filozofun hukuk felsefesi ve ceza adaleti yaklaşımının incelendiğinde ikinci bölüm de kendi içerisinde iki bölüm hâlinde incelenecektir. İlk bölümünde, genel olarak filozofun hak,

\footnotetext{
1 İMAMOĞLU, Kıymet Tuğba: Arthur Schopenhauer'da Metafizik Kötülük ve Varoluşun Verdiği Acıdan Kaçış Olarak Ahlaki Eylemler, İstanbul Medeniyet Üniversitesi Sosyal Bilimler Enstitüsü, Yayımlanmamış Yüksek Lisans Tezi, İstanbul, 2019, s.3-4; CAF, Bahar: Arthur Schopenhauer'da Pesimizmin Felsefesi, Van Yüzüncü Y1l Üniversitesi Sosyal Bilimler Enstitüsü, Yayımlanmamış Yüksek Lisans Tezi, Van, 2019, s.10,38 vd.

${ }^{2}$ MARCIN, Raymond B.: "Schopenhauer's Theory of Justice", Catholic University Law Review, 43(3), 1994, s.844; CAF, s.10.

${ }^{3}$ Makalemizin yazılmakta olduğu şuan itibariyle YÖK Tez Merkezi'nde başlı̆̆ında "Schopenhauer" ibaresi yer alan 41 adet tez yer almaktadır (https://tez.yok.gov.tr/UlusalTezMerkezi/ Erişim Tarihi: 26.12.2020). Bu tezlerin hiçbirisi Schopenhauer'ın hukuk felsefesini konu almamıştır. Yine Schopenhauer'ın Türkçeye kazandırılan onlarca kitabı vardır. Biz bu kitaplardan yirmi tanesini taramakla yetindik.

${ }^{4}$ SCHOPENHAUER, Arthur: İsteme ve Tasarım Olarak Dünya (İTD), Çev. Levent Özşar, 2. Bası, Biblos Kitabevi, İstanbul 2009, s.4.

${ }^{5}$ Atıf verilmeyen ancak taranan diğer kitapların başlıkları: Aşka ve Kadına Dair (Aşkın Metafiziği), Bilim ve Bilgelik, Bilmek ve İstemek, Cinsel Aşkın Metafiziği, Eristik Diyalektik - Haklı Çıkma Sanatı, Güzelliğin Metafiziği, Hayatın Anlamı, Okumaya ve Okumuşlara Dair, Ölümün Anlamı, Seçkinlik ve Siradanlık Üzerine, Üniversiteler ve Felsefe.

${ }^{6}$ Söz konusu tezler: ARSLAN, Ahmet: Arthur Schopenhauer'un Ahlak Felsefesi ve Pesimizm, Dokuz Eylül Üniversitesi Sosyal Bilimler Enstitüsü, Yayımlanmamış Yüksek Lisans Tezi, İzmir, 2019; CAF; İMAMOĞLU; KAYMAZ, Murat: Schopenhauer Felsefesinde Ahlakın Anlamı, Bahçeşehir Üniversitesi Sosyal Bilimler Enstitüsü, Yayımlanmamış Yüksek Lisans Tezi, İstanbul, 2018; VAHAPOĞLU BİNDESEN, Zehra: Arthur Schopenhauer'da Kötülük Problemi ve Mutluluğun İmkânı, Atatürk Üniversitesi Sosyal Bilimler Enstitüsü, Yayımlanmamış Doktora Tezi, Erzurum, 2019. İlgili monografiler: CARTWRIGHT, David E.: Schopenhauer, Çev. Sibel Erduman, 1. Bası, Türkiye İş Bankası Kültür Yayınları, İstanbul Nisan 2014; AYDOĞDU, Ahmet: Schopenhauer, 1. Bas1, Say Yayınları, İstanbul 2009; ATAYMAN, Veysel: Varolmanın Acısı: Schopenhauer Felsefesine Giriş, 1. Bası, Donkişot Yayınları, İstanbul 2004.
} 
adalet, devlet gibi hukuk felsefesiyle ilgili kavramlara verdiği anlamlar kısaca açıklanacaktır?. Schopenhauer felsefesiyle uyumlu bir hak kavramı inşa etmiş, adaleti anlamlandırmış ve devletin kökenine dair fikirler ortaya koymuştur. Filozof, hak kavramının doğal hukuk düşüncesine dayanan ahlakî bir zeminde ele almıştır. Filozofa göre, hak, devletten önce de vardır. Devlet bizatihi hakları korumak amaciyla kurulmuştur. Yine filozofa göre adalet, zamansal ve ebedî adalet olmak üzere ikili bir ayrıma tabi tutularak incelenmelidir. Filozof tarafindan "salt yasal doktrin" olarak da ifade edilen zamansal-adalet esasında bozuk bir adalet sistemi olarak telafi mekanizmasını ifade etmektedir. Ebedî adalet cezalandırıcı değil, merhamet edici metafizik bir yapıdayken; zamansal-adalet cezalandırıcı, dünyevî bir adalet mekanizmasını ifade etmektedir. Tüm bunların yanında filozof devleti sosyal sözleşmeyle kurulan "koruma kurumu" olarak tasarlamıştır. Filozofa göre devletin "iç koruma", "dış koruma" ve "kendinden koruma" şeklinde üç temel koruma işlevi vardır. Bu işlevler devletin varlık amacını teşkil etmektedir.

İkinci bölümdeyse Schopenhauer'ın ceza adaletine ilişkin yaklaşımı, cezalandırmanın anlamına ve amacına yönelik düşünceleri irdelenecektir. Schopenhauer'a göre cezalar bir telafi sistemi olan zamansal-adaletin ürünü olup faydayı amaçlar. $\mathrm{Bu}$ fayda caydırıcılıktır. Zira insan karakteri değiştirilemezdir ve insanların ıslah edilmesi mümkün değildir. Kefaret ise ahlakî bir kötülügüü ifade eder. O hâlde cezalandırmayla suça meyilli karaktere sahip insanlar korkutularak suç fiillerinden uzak tutulmalıdır. Ceza hukuku fail ceza hukuku değil, fiil ceza hukuku olmalı ve cezalandırmada orantılılı̆̆a dikkat edilmelidir. Son olarak Amerikan Ceza Sistemi'ni ve hücre cezalarını tartışan filozof tecrit sistemine şiddetle karşı çıkmış, bu cezaların hem amaca uygunluk bakımından başarısız, hem de -genel felsefesiyle uyumlu olarak- can sıkıntılarıyla insanlar için büyük bir işkence hâlini aldığına dikkat çekmiştir.

\section{SCHOPENHAUER'IN HAYATI VE GENEL FELSEFESI}

\section{A. Kant'ın Mirası}

Immanuel Kant, Schopenhauer henüz dünyaya gelmeden evvel felsefede adeta devrim yapmış, kendisinden önceki bütün felsefe geleneğini eleştirerek kendi felsefesini ortaya koymuştu. Schopenhauer'ın doğduğu 1788 yılında Kant ahlak felsefesini kurduğu eseri Kritik der praktischen Vernunft'u (Pratik Aklın Eleştirisi) yayınlamıştı. Kritik der reinen Vernunft (Saf Aklın Eleştirisi) yazılalı henüz yedi sene olmuş; Kritik der Urteilskraft (Yargl Gücünün Eleştirisi) başta olmak üzere pek çok önemli diğer eser henüz yayınlanmamıştı.

Kant'ın felsefede yaptığı devrim, Kant sonrası felsefenin belirleyicisi olmuştur. Kant sonrası felsefenin bir miras kavgası olduğunu söylemek yanlış olmayacaktır. Schopenhauer' in çağdaşları olan ve "Alman İdealistleri" olarak anılan Fichte, Schelling ve Hegel kendilerini Kant'ın mirasçısı olarak ilân etmiş, felsefelerini Kant'ın mirası üzerine inşa etmeye girişmişlerdi. Schopenhauer ise bu girişimi "şarlatanlıkla" suçlayıp kendisini Kant'in gerçek ve tek varisi ilân etmiştir'.

Schopenhauer'ın felsefesi, Kant'ın felsefî mirası üzerinden yükselmektedir. Gerçekten de Schopenhauer felsefesini ortaya koyarken Kant'la hesaplaşmış, Kantçı birç̧ok kavramı kullanmıştır. $\mathrm{Bu}$ itibarla Schopenhauer felsefesinin hakkıyla anlaşılabilmesi Kant'ın felsefî mirasının anlaşılmasından geçmektedir ${ }^{9}$.

Kant'1 harekete geçiren David Hume'un dogmatizm karşıtı felsefesi olmuştur. Kant, "beni dogmatik uykumdan uyandırdl" diyerek Hume'un kendi düşüncesi üzerindeki tesirini açıkça ifade etmiş̧ir. Dogmatik uykusundan uyanan Kant, Salt Aklın Eleştirisi'nde dogmatizmle mücadeleye girişmiş̧ir. Ancak Kant'ın mücadelesi yalnızca dogmatiklere karşı olmamış, aynı zamanda metafiziği felsefeden dışlayanlara (başta Hume'a) karşı da olmuştur ${ }^{10}$. Salt Aklın Eleştirisi'nde cevabı aranan temel sorular, "ne bilebiliriz" ve "nasıl bilebiliriz" sorularıdır. Kant bu sorulara cevap bulabilmek için insan aklını inceler. Kant'a göre insan aklı "teorik akıl" ve "pratik akıl" olmak üzere iki farklı işleve sahiptir. Teorik akıl "olan"la ilgilenmekteyken, pratik aklın ilgi alanı "olması-gereken"dir". Kant

\footnotetext{
${ }^{7}$ Ele aldığımız kavramların Hukuk Felsefesinin konusu kapsamında olduğuna dair ayrıca bkz. IŞIKTAÇ, Yasemin: Hukuk Felsefesi, 6. Bas1, Filiz Kitabevi, İstanbul Kasım 2019, s.451-452; SHINER, Roger A.: "Philosophy of Law", in Alston, William P. vd. (ed.), The Cambridge Dictionary of Philosophy, Cambridge Universtiy Press, New York 1999, s.676-677.

${ }^{8}$ SCHOPENHAUER, Arthur: Felsefe Tarihinden Kesitler (FTK), Çev. Ahmet Aydoğan, 1. Bası, Say Yayınları, İstanbul 2014, s.162.; SCHOPENHAUER, Arthur: Hukuk, Ahlak ve Siyaset Üzerine (HAS), Çev. Ahmet Aydoğan, 1. Bası, Say Yayınları, İstanbul 2009, s.9; MARCIN, s.816; CAF s.9,45; VAHAPOĞLU BİNDESEN, s. 17, 27; ARSLAN, s.2.

${ }^{9}$ VAHAPOĞLU BINDESEN, s. 16.

${ }^{10}$ HEIMSOETH, Heinz: Kant'ın Felsefesi, Çev. Takiyettin Mengüşoğlu, 6. Bası, Doğu Batı Yayınları, Ankara 2014, s.66.

${ }^{11}$ IŞIKTAÇ, s.184.
} 
pratik akla ilişkin argümanlarını genel itibariyle "Pratik Aklın Eleştirisi” kitabında tartışmış, Salt Aklın Eleştirisi'nde teorik aklı incelemiştir.

Kant'a göre deneyimden bağımsız bir bilgi olarak a priori bilgi ile deneyime dayanan ampirik bilgi birbirinden farklıdır. Kant'a göre ampirik bilgi salt duyulardan elde edilen bir bilgi değildir, şayet öyle olsaydı bu nevi bir bilgi kavramsal olmadığından kör bir bilgi olacaktı. O hâlde ampirik bilgiyi kavramsallaştıracak bir bilgi formu mevcut olmalıdır, bu form insan aklının kategorileridir ${ }^{12}$.

Kant yargıları da analitik ve sentetik olmak üzere ikiye ayırmaktadır. Analitik yargılar bir kavramı açıklayan yargılardır ve yeni bir bilgi ortaya koyamazlar. Sentetik yargılarsa bilgiyi genişleten, kavrama yeni bilgiler ekleyen yargılardır. Mesela elmanın meyve olduğu analitik bir bilgidir. Zira meyve olma elma kavramının içerisinde mevcut bir bilgidir, bu bakımdan elma hakkında yeni bir bilgi vermemektedir. Elmanın meyve olduğu bilgisine herhangi bir elmayı görmeden de ulaşmak mümkündür. Ancak elmanın yeşil veya kırmızı renkte olması sentetik bir bilgidir. Çünkü böyle bir bilgi elma kavramının içerisinde yer almayan renge dair bilgiyi elma kavramına hamlederek elma hakkındaki bilgimizi arttırmaktadır. Öyleyse tabiatları itibariyle ampirik bilgiler sentetik, a priori bilgilerse analitiktir.

Tam bu noktada Kant'a Salt Aklın Eleştirisi'ni yazdıran sorun ortaya çıkmaktadır: Metafizik yargılar tabiatları itibariyle a priori yargılardır, deneyimlenemezler. Buna karşın metafizik alandaki bilgimizi genişletebilmek için sentetik bilgilere ihtiyacımız vardır. Dolayısıyla metafizik alana ilişkin bir yargı tabiatıyla a priori, bilgimizin genişletilmesi amacını taşıdığından sentetik bir yargıya sahip olmalıdır. A priori sentetik yargı herhangi bir duyuma dayanmayan ve fakat yeni bir bilgi veren yargıdır. Hâlbuki böyle bir yargı biraz evvel yapılan tanımlamalar ile çelişmektedir ${ }^{13}$. Bu gerilimin Kant felsefesine göre çözümü başka çalışmanın konusudur. Ancak Kant'ın yaratmış olduğu bu gerilimin çalışmamız açısından önemi kendisini numen (kendinde-olan, noumenon) ve fenomen (görüngü, phainomenon) ayrımında ortaya koymaktadır.

Kant'a göre ampirik bilgi malzemesini "görünen dünyadan" almaktadır. Kant bilgi edinilebilen görünen dünyayı "fenomen" (görüngü) olarak isimlendirmektedir. Bunun karşısında insan deneyimini aşan, ampirik bilginin elde edilemediği bir alan vardır. Bu aşkın alan Kant'ın düşüncesinde "numen" olarak ifade edilmektedir. Numenal alan insan aklının kategorileri içerisine giremeyen saf bilgileri ihtiva etmektedir. Bu sebeple numenal alan Kant'ın tabiriyle "transandantal" (aşkın) bir alan olup bu alana dair bilgi edinmemiz mümkün değildir. Numen-fenomen kavramları Kant felsefesi açısından oldukça önemli bir yere sahipken aşağıda ayrıntısıyla açıklanacağı üzere çalışmamızın ana odağını teşkil eden Schopenhauer felsefesinde de yeni bir hüviyete bürünerek kilit bir nokta teşkil edecektir.

\section{B. Schopenhauer'm Genel Felsefesi}

Schopenhauer kötümser (pesimist) felsefesiyle ünlenmiş bir filozoftur. Gerçekten de Schopenhauer denildiğinde akla ilk gelen filozofun karamsar dünya görüşüdür. Ancak Schopenhauer'in kötümserliği salt duygusal edebî bir tavırdan ibaret olmayıp felsefî zemine oturan bir dünya görüşüdür. Bu başlık altında filozofun felsefi dünya görüşü kısaca incelenecektir.

\section{Varlık Felsefesi}

Schopenhauer'n temel eseri 1819 tarihli Die Welt als Wille und Vorstellung kitabıdır. Schopenhauer felsefesinin genel hatlarını bu eserde şekillendirmiştir. Kitap ismini Schopenhauer felsefesi için temel kavramlar olan "irade" (isteme, istenç, "will", "Wille") ve "tasavvur" (tasarım, temsil, "representation", "Vorstellung") kavramlarından almıştır.

Schopenhauer felsefesinde merkezi kavram "isteme" kavramıdır ${ }^{14}$. Zira tasavvur bir istemenin tasavvuru olmakla birlikte istemeden sonra gelmektedir. Schopenhauer felsefesinde isteme bölünemez, tek, evrensel bir istemedir ${ }^{15}$. İsteme her şeyin temelinde var olan ve tüm varllğ 1 kendisinde dolayımlayan “kendinde-şey”dir". Bu bakımdan Schopenhauer'ın isteme kavramıla Kant'ın numen

\footnotetext{
${ }^{12}$ MARCIN, s.821.

${ }^{13}$ HEIMSOETH, s.74-75.

14 "İsteme" olarak ifade ettiğimiz kavram "irade" kavramıdır. Schopenhauer felsefesinde "isteme” olarak ifade ettiğimiz özel bir irade kavramı mevcuttur. Biz bu kavramı klasik anlamdaki iradeden ayırmak için "isteme" demeyi tercih ettik. Çalışmamız boyunca irade ve isteme kavramlarının bir arada kullanıldığı cümlelerde bu tercihimizin sebebi daha iyi anlaşılacaktır.

${ }^{15}$ SCHOPENHAUER, Arthur: The World as Will and Representation v. I (WWR1), Trans. Christopher Janaway, 1. Press, Cambridge University Press, Cambridge 2010, s.144, 153; SCHOPENHAUER, İTD, s.64, 72; MARCIN, s.829; ARSLAN s.17, VAHAPOĞLU BİNDESEN, s.30.

${ }^{16}$ SCHOPENHAUER, WWR1, s.24; SCHOPENHAUER, ITD, s.9-10; MARCIN, s.831, 844; ARSLAN s.14, 17; CAF s.15; İMAMOĞLU, s.12; VAHAPOĞLU BİNDESEN, s.120; KAYMAZ, s.2.
} 
kavramının oldukça benzer olduğunu söylemek mümkündür ${ }^{17}$. Ancak numen ve "isteme" kavramları arasında önemli bir fark vardır: Kant, numen alana dair insan bilgisinin mümkün olmadığını ileri sürerken; Schopenhauer, bu alana dair bilgimiz olabilec ĕgini iddia etmektedirir ${ }^{18}$.

Kant'taki fenomen kavramının karşılığı ise Schopenhauer felsefesinde "tasavvur" olarak ortaya çıkmaktadır. Gerçekten de hakikatte var olan tek şey istemedir. Çokluklar ve farklılıklar tasavvurattaki (fenomenler alemindeki) bir yanılsamadan başka bir şey değildir ${ }^{19}$. Kendinden şey olan istemeyi tek tek bireylerin iradeleriyle karıştırmamak gerekir. Her şeyi belirleyen isteme, Schopenhauer'a göre kördür ${ }^{20}$. Kör istemenin tek isteği var olmak ve varlığını sürdürmektir ${ }^{21}$. İsteme varlığını sürdürmek amacıyla tasavvuratta var olan her şeyi araç olarak kullanır. Böylelikle her şey gibi insan da istemenin bir kuklasından ibaret olur ${ }^{22}$. İsteme için tekil bireyin herhangi bir kıymeti yoktur, mühim olan türün devamlılı̆̆ıdır. İsteme bu amacını gerçekleştirmek için tekilin arzularını kullanır.

Arzu (güdü / motif) kavramı, Schopenhauer'ın "kötümser" dünya görüşünün neşet ettiği membadır. İnsan tabiatı, arzuların tabiatıdır. İnsan, arzular yoluyla istemenin emrinde hareket etmektedir ${ }^{23}$. Arzular kendisini tasavvuratta var eder. Arzular sayesinde özünde tek olan isteme bölünür ve çoğulu var eder. Arzu, tekliği parçalayarak bireyselleşmeyi ortaya çıkartır ${ }^{24}$. Bireyselleşme; egoizmin, bencilliğin ve tüm kötülüklerin kaynağıdır ${ }^{25}$.

Schopenhauer'a göre arzuların bir sonu yoktur. İnsan sürekli istemekte, bir arzusu bittiğinde yeni bir arzusu ortaya çıkmaktadır ${ }^{26}$ Bu arzular insanlığın belasıdır. Arzu duyan insan arzuladığına kavuşmadığı müddetçe acı çekmekte, kavuştuğundaysa hemen yeni bir arzuyla 1stırab1 yenilenmektedir. Olur da arzular derhâl yerine getirilecek olsa yahut arzulanacak bir şey kalmayacak olsa artık can sıkıntısı insanın başına bela olur. Herhangi bir arzusu kalmayan insan can sıkıntısından patlar, intihar eder veya sanal arzular yaratarak bunlara tutunmaya çalışır $1^{27}$. $\mathrm{O}$ hâlde insan için dünyada mutlu olmak mümkün değildir.

Schopenhauer'in kötümserliğinden "insan" da nasibini almıştır. Filozofa göre dünyadaki kötülüğün bir kaynağı da insandır. İnsanda iyi ve güzel namına bir şey bulmak pek mümkün değildir. İnsan doğuştan kötüdürr ${ }^{28}$. İnsandaki kötülüğün kaynağı arzuların insana dayatmış olduğu bencillik ve egoizmdir ${ }^{29}$. Schopenhauer'a göre insan hazzı için her türlü kötülüğü yapabilecek bencil bir varlıktır. $\mathrm{Bu}$ bencilliğin sebebi ise merhametsizliktir ${ }^{30}$.

\section{Ahlak Felsefesi}

Schopenhauer'ın ahlak felsefesinde temel kavramlar, "karakter" ve "merhamet" kavramlarıdır. Filozofa göre insan karakterinin dört özelliği vardır. Bunlar; bireysellik, ampiristlik, değişmezlik ve doğuştanlıktır ${ }^{31}$.

Bireysellik, arzuların insana dayattığı bir durumdur. Ahlakîliğin yegâne kaynağı karakterin bir özelliği olan bireyselliğin aşılmasıyla duygudaşlığın getirdiği merhamet duygusudur ${ }^{32}$. İnsan

\footnotetext{
${ }^{17}$ VAHAPOĞLU BINNDESEN, s.3, 18.

${ }^{18}$ VAHAPOĞLU BINDDESEN, s.25.

${ }^{19}$ MARCIN, s.847. RUGGIERI, Davide: "The metaphysics of conlict: some reflections on Schopenhauer's politics", Voluntas Revista Internacional de Filosofia, 7(1), 2016, s.150; KAYMAZ, s.3. Schopenhauer'a göre her insan Adem'dir, tıpk1 her insan İsa olduğu gibi... (bkz. MARCIN, s.851).

20 SCHOPENHAUER, WWR1, s.174; SCHOPENHAUER, ITTD, s.91; MARCIN, s.850; ARSLAN, s.1,15,16; VAHAPOĞLU BINDESEN, s.36,41,147; IMAMOĞLU, s.12,29; KAYMAZ, s.2; ÇALIŞKAN AKÇETIN, Nurhayat: "Merhamet ve Devlet: Schopenhauer", Felsefe ve Sosyal Bilimler Dergisi, (21), 2016, s.74.

${ }^{21}$ SCHOPENHAUER, WWR1, s.338; SCHOPENHAUER, ITTD, s.231; CAF s.15, IMMAMOĞLU 29; KAYMAZ, s.2-3.

${ }^{22}$ ARSLAN s.16.

${ }^{23}$ ARSLAN, s.16.

${ }^{24}$ Schopenhauer bireyselleşmeyi principium individuationis (bireysellik ilkesi) olarak ifade etmektedir.

${ }^{25}$ ÇALIŞKAN AKÇETIN, s.73.

${ }^{26}$ SCHOPENHAUER, ITD, s.231; SCHOPENHAUER, Arthur: Okumak, Yazmak ve Yaşamak Üzerine (OYY), Çev. Ahmet Aydoğan, 2. Bası, Say Yayınları, İstanbul 2008, s.42; ARSLAN s.17; CAF, s.56; VAHAPOĞLU BİNDESEN, s.176; ÇALIŞKAN AKÇETIN, s.76.

27 SCHOPENHAUER, İTD, s.237, 294; SCHOPENHAUER, OYY, s.42; CAF, s.56; ARSLAN s.17; VAHAPOĞLU BINNDESEN, s.176.

${ }^{28}$ CAF, s.26; ARSLAN, s.43; VAHAPOĞLU BINDESEN, s.40.

29 SCHOPENHAUER, WWR1, s.358-359; SCHOPENHAUER, İTD, s.245-246; CAF, s.26,30; ARSLAN, s.21,37; VAHAPOĞLU BINNDESEN, s.41,126; İMAMOĞLU, s.13,37; ÇALIŞKAN AKÇETIN, s.

30 SCHOPENHAUER, WWR1, s.358-359; SCHOPENHAUER, ITD, s.245-246; CAF, s.20, ARSLAN, s.37,150; VAHAPOĞLU BİNDESEN, s.33.

${ }^{31}$ KAYMAZ, s.38.

${ }^{32}$ CAF, s.30, ARSLAN, s.36; VAHAPOĞLU BİNDESEN, s.43; İMAMOĞLU, s.126, 128; ÇALIŞKAN AKÇETİN, s.78.
} 
merhametle birlikte bencillikten kurtularak ahlakî bir yaşama sahip olabilir ${ }^{33}$. Merhamet, bencilliğin temelinde yer alan bireyselliği ortadan kaldırıp duygudaşlık üzerinden "ben ve öteki"nin birliğini sağlar ${ }^{34}$. Merhametle birlikte tasavvurattaki çokluğun yanılsama olduğu, herkesin herkesle tek ve bir olan istemenin tasavvurları olduğunun farkına varılır. Böylece insan merhametle bencilliği ve individuationisi yenebilir.

Filozofa göre karakter ampiriktir. Kişi istediği fiilleri özgürce yapabildiğini sanmaktadır, peki istediklerini isteyip istemediğini nereden bilmektedir? Schopenhauer'a göre insan, bu sorunun cevabını bilemez çünkü kendi karakterine yabancıdır. İnsan kendi karakterini birtakım olaylar karşısında göstermiş olduğu tepkileri deneyimleyerek tanır ${ }^{35}$. Bu itibarla kişi, karşılaşmadığı bir durum karşısında nasıl bir tepki vereceğini hiçbir zaman bilemez ${ }^{36}$.

Schopenhauer karakterin doğuştan geldiğini ve değiştirilemeyeceğini düşünmektedir ${ }^{37}$. İnsanın var sandığ 1 irade bir yanılsamadır ${ }^{38}$. Fiillerinde özgür olan tek irade istemenin iradesidir, ancak istemenin iradesi de kördür ${ }^{39}$. Bu sebeple, ayrıntıları aşağıda yer alacağı üzere, Schopenhauer insanların eğitilmesinin mümkün olmadığını, insanların ancak güdülenebileceğini düşünmektedir ${ }^{40}$. İnsanda özgür irade mümkün olmadığı gibi doğada da özgür irade yoktur. Olan her şey zorunlu olarak gerçekleşir, olup bitenlere katı bir zorunluluk hâkimdir ${ }^{41}$. Schopenhauer böyle bir zorunluluk mevcut olmasaydı dünyanın varlığını devam ettiremeyeceğini düşünmektedir ${ }^{42}$.Olup biten her şey istemenin kör iradesinin eseridir.

O hâlde aynı kişinin aynı mevzuudaki farklı davranışları nasıl açıklanabilir? Bu sorunun cevabı fizikî imkânda bulunur. Schopenhauer'ın fikirleri bir örnekle somutlaştırılabilir: İçinde insan öldürmeye dair arzu taşıyan bir cani, böyle bir fiili neticesinde müebbet hapis cezasıyla cezalandırılacağını bilir. Bu sebeple arzusunu yerine getiremez. Ancak bir savaş meydanında böyle bir imkâna sahip olursa düşmanını zorunluluktan dolayı değil zevkle öldürür. Değişen karakter değil, dış koşullardır. Fail, uygun koşulları bulduğunda daima karakterini ortaya koyar ${ }^{43}$.

$\mathrm{Bu}$ fikirler filozofun özgür iradeyi daha ayrıntılı olarak incelemesini gerektirmiştir. Schopenhauer iradenin özgürlüğünü üç bakımdan ele alır. Bunlar fiziksel, entelektüel ve ahlakî özgürlüktür ${ }^{44}$. Fiziksel özgürlük failin fiilini gerçekleştirirken herhangi bir engelle karşılaşmaması durumunu ifade eder. Örneğin mücevheri çalmak isteyen kişi, kasa kapısı kilitli olmadığında mücevheri çalmakta fiziksel olarak özgürdür. Filozofa göre politik özgürlük, fiziksel özgürlük alanında yer almaktadır. Devlet fiziksel engellerle (örneğin kolluk güçleri, hapis tehdidi) kişileri belirli fiillerden alıkoymak ister, özgürlükleri kısıtlar ${ }^{45}$. Entelektüel özgürlük ise failin zihnî melekelerinin tam olmasını ifade eder. Örneğin bir akıl hastası fiillerinde özgür değildir. Schopenhauer tarafindan sayılan son özgürlük alanı olan ahlakî özgürlükse hukukta irade ve kusur tartışmalarının gündeme geldiği irade hürriyetinin tartışıldığı özgürlük alanıdır. Bu alanda filozof katı bir zorunluluğun mevcut olduğunu ve ahlakî karakterin değiştirilemeyeceğini düşünür.

\section{SCHOPENHAUER'IN HUKUK FELSEFESİ VE CEZA ADALETI}

Schopenhauer yukarıdaki felsefî görüşlerinin yanı sıra hukuka ilişkin fikirler de ortaya koymuş bir filozoftur. Gerçekten de Schopenhauer' in genel felsefesinin hukuka; hususiyetle devlet, adalet ve ceza gibi temel hukukî kavramlara temas eden pek çok farklı görüşü bulunmaktadır. Bu bölümde Schopenhauer'ın hukuk felsefesi görüşleri incelenecektir.

\footnotetext{
${ }^{33}$ MARCIN, s.853; CAF, s.33; ARSLAN s, 21, 33, 37; VAHAPOĞLU BİNDESEN, s.146.

34 SCHOPENHAUER, HAS, s.89; VAHAPOĞLU BINDESEN, s.33; MARCIN, s.845; RUGGIERI, s.151; ÇALIŞKAN AKÇETIN, s.78.

${ }^{35}$ SCHOPENHAUER, Arthur: The Two Fundamental Problems of Ethics (TTF), Trans. Christopher Janaway, 1. Press, Cambridge University Press, Cambridge 2009, s.68; KAYMAZ, s.39.

${ }^{36}$ SCHOPENHAUER, TTF, s.69; KAYMAZ, s.39.

${ }^{37}$ SCHOPENHAUER, HAS s.89; SCHOPENHAUER, Arthur: The World as Will and Representation v. II (WWR2), Trans. E. F. J. Payne, 1. Press, Dover Publications, Inc., New York 1966, s.597; SCHOPENHAUER, TTF, s.106; WOODS, David: "Seriously bored: Schopenhauer on solitary confinement", British Journal for the History of Philosophy, 27(5), 2019, s.962; G.V.DER KROON, Annette: "A. Schopenhauer's theory of justice and its implication to natural law", Jahrbuch der Schopenhauer-Gesellschaft 2003, 84(-), 2003, s.129; VAHAPOĞLU BİNDESEN, s.46, 63; KAYMAZ, s.40.

${ }^{38}$ SCHOPENHAUER, TTF, s.69; G.V.DER KROON, s.126, 129; VAHAPOĞLU BİNDESEN, s.59; ARSLAN, s.44.

${ }^{39}$ MARCIN, s.849; G.V.DER KROON s.125; RUGGIERI, s.147; KAYMAZ, s.45.

${ }^{40}$ WOODS, s. 962

${ }^{41}$ SCHOPENHAUER, TTF, s.79; KAYMAZ, s.39.

42 SCHOPENHAUER, TTF, s.80.

${ }^{43}$ SCHOPENHAUER, TTF, s.69; KAYMAZ, s.30. Krş. ARSLAN, s.35.

${ }^{44}$ Bu üç özgürlük alanıyla ilgili bakınız: KAYMAZ, s.24 vd.

${ }^{45}$ KAYMAZ, s.24.
} 


\section{A. Schopenhauer'da Hukuk ve Devlet Anlayışı}

\section{1. "Hak" Kavramı}

Hukuk, Arapça bir kelime olup "hak" kelimesinin çoğuludur ${ }^{46}$. Hukukun temelinde haklar vardır. Bu sebeple Schopenhauer'ın hukuk felsefesini incelemeye "Schopenhauer'da hak kavramı"nın incelenmesiyle başlanabilir. Schopenhauer'e göre hak, devletten bağımsız bir varlığa sahiptir. Haklar devletlerden önce de vardı. Devletler yalnızca hakkın koruyucusudur ${ }^{47}$. Sözgelimi mülkiyet hakkıyla dünyaya gelme hakkı arasında bir benzerlik vardır. Nasıl insanlar genetik miras taşıyorlarsa, aynı şekilde servet mirası da doğuştan gelen bir haktır. O hâlde Schopenhauer'da özel mülkiyet gibi liberal düşünce tarafından tanınan doğal hakların mevcut olduğunu kabul etmek gerekir. Doğal hukuk düşüncesi, tarihsel bağlama göre farklı muhtevaya bürünmekle birlikte, genel olarak siyasi iktidarın koymuş olduğu kanunların hukukun yegâne kaynağı olmadığını, devletlerden ve yürürlükteki pozitif kanunların üstünde bir hukukun mevcut olduğunu savunan hukuk felsefesi doktrinidir ${ }^{48}$. Dolayısıyla haklar doğada (veya insanın tabiatında) kendiliğinden vardır ${ }^{49}$. Bu düşünceler, Schopenhauer'ın da doğal hukuk yaklaşımına yakın bir anlayışa sahip olduğunu göstermektedir ${ }^{50}$.

Filozof ahlak ilehukuk arasında da bir fark yaratmak niyetindedir. Filozofa göre hukuk insanların haksız acı çekmesinin önüne geçmek gibi "koruyucu" "kötü" denilebilecek yanlış davranışlar belirleyen normlardır ${ }^{52}$. Aynı şekilde hukuk sisteminin ödül ve ceza temelli bir yapıya sahip olması, hukukun insan güdülerine yöneldiğini, bu anlamda hukuka tabi olmak amacıyla yapılan fiillerin zorunlu olarak bencil eylemler olduğunu göstermektedir. Hukukî fiillerin saf ahlakî fiil olması mümkün değildir ${ }^{53}$. Ahlakî normlar içe, hukuk normu dışa dönüktür.

Filozofun hakkın içeriğine dair de fikirleri vardır. "Hak" menfi bir kavramdır. Diğer bir ifadeyle Schopenhauer'a göre hak (adalet), hakkı vermek değil, haksızlık etmemektedir ${ }^{54}$. Bunun gibi özgürlükler de menfi karaktere sahiptir. Filozofa göre özgürlük başkasının hakkına tecavüz edilmediği müddetçe her şeyi yapabilme kabiliyetini ifade eder ${ }^{55}$. Haksızlık bir kişinin aleyhine olacak şekilde çıkar elde etmektir. Haksızlığın boyutu kişiye verilen zarar ile elde edilen kâra eşittir ${ }^{56}$. Bu itibarla zenginden yüz taler çalmakla fakirden yüz taler çalmak arasında fark vardır ${ }^{57}$.

Filozofa göre insanların hakları eşittir. Doğanın insanlara vermiş olduğu kudret ve kabiliyetler farklı farklı olsalar da ahlakî zeminde her insan eşit haklara sahiptir ${ }^{58}$. Aşağıda ifade edileceği üzere, devletin görevlerinden biri de acıların homojen dağılımını tesis ederek insanlar arasında eşitlik sağlamaktır.

\section{Adalet Kavramı}

Schopenhauer felsefesinde adalet kavramı hukukî olmanın ötesinde ontolojik ve metafizik bir anlama sahiptir. G.V.der Kroon'a göre Schopenhauer'da üç tür adalet kavramından bahsetmek mümkündür ${ }^{59}$. Bunlar; "ebedi-adalet", "gönüllü-adalet" ve "zamansal-adalet veya salt yasal doktrin”dir. Buna karşın Ruggieri’ye göre Schopenhauer'da "ebedi-adalet” ve "zamansal-adalet"

\footnotetext{
${ }^{46}$ GÜRİ, Adnan: Hukuk Felsefesi, 13. Bası, Siyasal Kitabevi, Ankara 2018, s.121.

${ }^{47}$ SCHOPENHAUER, WWR2, s.594; SCHOPENHAUER, HAS, s.85-86; ÇALIŞKAN AKÇETIN, s.80.

${ }^{48}$ GÜRIZ, s.137; UYGUN, Oktay: Hukuk Teorileri, 2. Bask1, On İki Levha Kitabevi, İstanbul Haziran 2020, s. 5; USLU, Cennet: İnsan Haklarının Felsefi Temelleri: Doğal Hukuk ve Doğal Haklar, Hacettepe Üniversitesi Sosyal Bilimler Enstitüsü, Yayımlanmamış Doktora Tezi, Ankara 2007, s. 15-16.

${ }^{49}$ USLU, s. 16.

${ }^{50}$ Makalemizde Schopenhauer'ın doğal hukukçu olduğunu kanıtlamak gibi bir çabamız yoktur! Çalışmamızın amacı Schopenhauer'ın fikirlerini Türk doktrinine tanıtmaktır. Ancak çalışmamız neticesinde Schopenhauer'ın fikirlerinin doğal hukuk ile izahının mümkün olabileceği sonucuna varılmıştır. Aradaki ilginin ayrıntısı farklı bir çalışmanın konusu olup bizim çalışmamızın maksadını aşmaktadır!

${ }^{51}$ Devletin koruyuculuk yükümlülüğü aşağıda ayrıntılı olarak incelenecektir.

${ }^{52}$ SCHOPENHAUER, TTF, s.210; G.-V.DER KRONN, s.3-4.

${ }^{53}$ Schopenhauer burada Kant'ın koşulsuz buyruğa dayalı ahlak anlayışına zımnen atıf yapmaktadır. Daha açık bir söyleyişle Kant'ta ahlakî eylemin koşulsuz buyruğun bir sonucu olup herhangi bir fayda gütmemesi gerektiği gibi, Schopenhauer'a göre de hukukî fiiller ceza ve ödül temelli yapıya sahip olduğundan saf ahlakî eylem olamayacaktır. Bu düşünce bir sonraki başlıkta daha net anlaşılacaktır.

${ }^{54}$ Schopenhauer "herkese hakkını ver!” şeklindeki doğal hukuk düşüncesini “pesimist” yaklaşımıyla baş aşağı çevirmiştir.

${ }^{55}$ SCHOPENHAUER, TTF, s.208; SCHOPENHAUER, HAS, s.84; SCHOPENHAUER, Arthur: Parerga ve Paralipomena Cilt II (PVP), çev. Gürkan Başay/Murat Kaymaz, Ötüken Neşriyat, İstanbul 2021, §121; ÇALIŞKAN AKÇETİN, s.79.

${ }^{56}$ SCHOPENHAUER, TTF, s.210.

${ }^{57}$ SCHOPENHAUER, TTF, s.224.

${ }^{58}$ SCHOPENHAUER, PVP, $\$ 122$.

${ }^{59}$ G.-V.DER KRONN, s.1.
} 
olmak üzere iki çeşit adalet düşüncesi mevcuttur. Gönüllü-adaletse ebedî adaletin bir parçasıdır. Biz Ruggieri'nin yaklaşımına katılmaktayız ${ }^{60}$.

Schopenhauer felsefesine göre ebedi-adalet istemenin doğasında var olan adalettir ${ }^{61}$. Bu adalet insan tarafından yaratılmış veya insanın müdahalesi olabilecek bir adalet değildir. İnsan ancak gönüllü olarak bu adalete tabi olmaya çalışabilir.

Ebedî-adalet iki şekilde tecelli eder: Birincisi Schopenhauer'ın varlı̆̆ın aslında tek bir istemenin tezahürü olduğu, bu anlamda bireyselliğin ve bencilliğin bir yanılsamadan ibaret olduğu düşüncesiyle ilişkilidir. Buna göre zulmedenle mazlum esasında birdir, aynı varlığın tasavvurlarından ibarettir. Zulmeden zaten kendisine zulmetmektedir, mazlumsa kendisinden zulüm görmektedir. Dolayisıyla mağdur ve fail sıfatları aynı kişide, istemede, birleşmektedir. Ebedî-adaletin ikinci gerçekleşme biçimiyse, Schopenhauer'ın çokça etkilenmiş olduğu uzak doğu dinlerindeki, reenkarnasyon anlayışında kendini bulmaktadır. Bu anlayışa göre zulmeden sonraki hayatında mazlum olacaktır. Öyleyse ebedî-adalet tasavvurattaki cezalandırıcı bir adalet değildir. Hakikatin özünde var olan, aşkın boyuttaki bir adalettir ${ }^{62}$. Ebedî-adalet varlı̆̆ın özünde vardır ve kaçınılmazdır.

Ebedî-adalet transandantal bir adalettir. İnsanlar yalnızca gönüllü olarak bu adalete tâbi olabilirler. Bu durum Schopenhauer felsefesinde "gönüllü-adalet" olarak ifade edilmiştir. Bu adalet türü, "merhamet" olarak ifade edilen ahlakî edemin bir uzantısıdır. Herkes herkesle birdir ve tek olan istemenin tasavvurundan ibarettir. Ancak transandantal düzeyde birlik mevcut olsa da tasavvuratta bireysellik yasası hâkimdir. Ahlaklı kişi, diğerinin çekmiş olduğu ıstıraba bakarak duygudaşlı̆̆ının farkına varan ve diğerine merhamet duygularıyla bağlanan kişidir ${ }^{63}$. İşte bu merhamet, ceza korkusuyla yasaya uymak şeklindeki sözde adaletten ayrılır. Merhamet Kant' in koşulsuz buyruk olarak ifade ettiği ahlak yasasına benzer şekilde kişinin çıkar gözetmeden ebedî adalete tabi olmasını ifade eder. Merhamete dayanan bu adalet Schopenhauer felsefesinde "gönüllü-adalet" olarak ifade edilir ${ }^{64}$.

Schopenhauer felsefesindeki diğer adalet türüyse zamansal-adalet veya salt yasal doktrindir. Bu tür bir adalet esasında "baş aşağı dönmüş bir adalet"tir ${ }^{65}$. Zira Schopenhauer'a göre saf ahlakın gerçekleştiği bir durumda devlete ihtiyaç olmazd ${ }^{66}$. Saf ahlakla bir arada olamayan bir adalet, gerçek bir adalet değildir. Böyle bir adalet, adaletsizliği telafi etmek için var olan bir adalettir ve tali bir değere sahiptir. Bir telafi mekanizması olan dünyevî zamansal-adalet, ebedî-adaletten farklı olarak cezalandırıcı bir özelliğe sahiptir ${ }^{67}$. Zamansal-adalet yasalarla insanı güdülemeye çalışır, bu itibarla ahlakî zeminde değildir ${ }^{68}$. Bir fayda beklentisi mevcuttur. Hukukun veya kanunların temsil ettiği bu adaletin bir diğer adı salt yasal doktrindir.

İki adalet türü arasındaki fark, şu örnekle daha iyi ifade edilebilir: (A) kişisi, (B) kişisini kasten yaralamıştır. Schopenhauer'a göre (A) kişisi ile (B) kişisi esasında aynı kişidir. Birisinin (A), birisinin (B) olması bir yanılsamadan ibarettir. Öyleyse ebedî-adalet boyutunda (A) kendisine kötülük etmiş, (B)'yse kendisinden kötülük görmüştür. Çünkü (A) ile (B) birdir. Olayda (B), ebedî-adalete tâbi olmak suretiyle (A)'ya merhamet gösterir, esasında aynı kişi olduklarının farkına varıp ona verilecek cezayla esasında kendisine acı verileceğini fark ederse gönüllü-adalet gerçekleşecektir. Ancak tasavvuratta işler bu şekilde yürümemektedir. Düzenin mevcut olabilmesi, (A) gibilerin güdülenebilmesi ${ }^{69}$, benzer hadiselerin tekrar yaşanmaması için (A)'nın bir cezaya çarptırılması gerekir. Bu ceza zamansaladaletin bir gereğidir. Şayet insanlar birbirilerini yaralamasaydılar böyle bir adalete ihtiyaç kalmazdı. Bu bakımdan zamansal-adalet telafi edici bir adalet türüdür, esasında adil değildir.

\footnotetext{
${ }^{60}$ Schopenhauer üç çeşit adaletten bahsetmektedir. Der Kroon bu sebeple üçlü ayrıma gitmektedir. Ancak Schopenhauer düşüncesine göre ebedî-adalet varlığın kendinden sahip olduğu adaleti, zamansal-adalet ise hukuk düzenini tarafindan yaratılan adaleti ifade etmektedir. Üçüncü adalet tipi olan gönüllü-adalet, ebedî-adalete kişinin gönüllü tabiyetini ifade ettiğinden Ruggieri'ye göre ebedî-adaletin bir parçası olarak ele alınması gerekmektedir. (Bkz. G.-V.DER KRONN, s.121; RUGGIERI, s.151.)

${ }^{61}$ G.-V.DER KRONN, s.121.

${ }^{62}$ G.-V.DER KRONN, s.121-122.

${ }^{63}$ Schopenhauer felsefesinde merhamet kavramının anlamını daha ayrıntılı olarak hatırlamak için Schopenhauer'ın genel felsefesi bölümüne müracaat edilebilir.

${ }^{64}$ G.-V.DER KRONN, s.3; RUGGIERI, s.151.

${ }^{65}$ RUGGIERI, s.148.

${ }^{66}$ SCHOPENHAUER, PVP, §123; RUGGIERI, s.150.

${ }^{67}$ Aşağıda Schopenhauer'ın Ceza teorisi incelenirken Schopenhauer'ın bu konudaki düşünceleri daha ayrıntılı olarak açıklanacaktır.

${ }^{68}$ ÇALIŞKAN AKÇETIN, s.73.

69 “Güdülenebilmek" ifadesinin anlamı çalışmanın ilerleyen bölümlerinde daha anlaşılır olacaktır.
} 


\section{Devletin Kökeni}

Schopenhauer doğal yaşamın tehditlerle dolu olduğunu, insanların bu tehditlerle tek başına başa çıkamayacaklarını düşünmektedir. Devlet, varlık sebebini tehditlerde ve adaletsizliklerde bulur. Ona göre insanlar korunmak amaciyla bir araya gelerek bir "koruma kurumu" yaratmışlardır. Bu kurum devlettir $^{70}$. Görüldüğü gibi Schopenhauer, devletin kökenini açık bir şekilde sosyal sözleşmede bulmaktadir ${ }^{71}$.

Schopenhauer'a göre "sana nasıl davranılmasını istiyorsan, sen de başkalarına öyle davran" ilkesi rasyonel adaletin en yüce ilkesidir. Bu ilkenin temelinde duygudaşlığa dayanan merhamet düşüncesi yer almaktadır. Merhamet filozofa göre doğa durumunda bile mevcut olan duygudur. Zira merhamet duygusu, insan bencilliğini yumuşatarak türün varlığının sürdürülmesine katkı sağlar. Bu duyguyla doğa durumunda bile güçlü bir hırsız, zayıf bir çocuğu soymaktan çekinir ${ }^{72}$. Merhametin erdemlerin ilki olduğu düşüncesi her çağda ve ülkede ahlakın kaynağını teşkil etmiştir ${ }^{73}$. Schopenhauer'ın bu düşünceleri evrensel bir ahlak anlayışı benimsediğini, devletten önce bir doğa durumunun mevcut olduğunu ve insanların bir sözleşmeyle devleti kurdukları şeklinde pek çok doğal hukukçu tezle paralellik arz etmektedir ${ }^{74}$.

Schopenhauer'a göre sözleşmeyle kurulan devletin bazı görevleri mevcuttur. Bunlardan ilki “ $d \iota s ̧$ koruma"dır. Dış koruma, devletin vatandaşlarını doğal güçlerden ve yabancı insanlardan korumasıdır ${ }^{75}$. Zira "insan insanın kurdudur" (homo homini lupus) ${ }^{76}$. Doğadaki her canlıda arzu ve egoizm vardır. Ancak bilinç seviyesi en yüksek olan insanda egoizm had safhadadır ${ }^{77}$. Bu sebeple insan vahşi ve adaletsiz bir tabiata sahiptir. Her insan başlangıçta istemenin ve arzularının eseri olarak şiddete ve adaletsizliğe meyillidir ${ }^{78}$. Bunun anlaşılabilmesi için suç hikayelerine ve anarşi durumlarına bakmak yeterlidir ${ }^{79}$. İnsanlar bencil olduklarından başkalarına acı vermeyi arzularını tatmin için mubah saymaktadır ${ }^{80}$. Devlet ortadan kalksa, tabiatları gereği bencil olan insanlar hemen vahşet hâline geri döneceklerdir ${ }^{81}$. Schopenhauer bu düşüncesini şöyle bir aforizmayla dile getirmiştir: "Devletler, insanların sinırsı adaletsizliğine bir set çekme önleminden başka nedirler ki?" 22

Schopenhauer'ın bu düşünceleri açıkça Hobbes'un fikirlerini hatırlatmaktadır ${ }^{83}$. Gerçekten de Schopenhauer devletin ortaya çıkışını çok defa Hobbes, Locke ve Rousseau gibi sosyal sözleşmeci filozoflara atıfla açıklamıştır. Schopenhauer'a göre Hobbes devletin kökenini tamamen doğru bir şekilde ortaya koymuştur ${ }^{84}$. Hobbes'un fikirleri hatırlanacak olursa Hobbas'a göre "insan insanın kurdudur". İnsanlar doğa durumundayken sürekli bir savaş hâlindedirler. Böyle bir savaş durumunun devamı mümkün olmadığından insanlar bir araya gelerek güçlerini üstün bir otoriteye devretmişler, böylece otorite altındaki eşitler olarak barış içinde yaşamaya başlamışlardır. Bu üstün otorite devlettir ${ }^{85}$. Bununla birlikte Schopenhauer Hobbes ve Rousseau'nun "doğa durumu" konusundaki ihtilafına da değinerek her ki düşünürün fikirlerini de eleştirmektedirr ${ }^{86}$. Ancak Rousseau'nun insanın tabiatında merhamet duygusunu taşıdığı yönündeki görüşüyle Hobbes’taki büyük eksikliği fark ettiğini düşünmektedir ${ }^{87}$. Filozof fikirlerinin "tüm modern çağın en büyük ahlakçısının otoritesi" olan J. J. Rousseau'ya dayandığını ifade ederek onu "bilgeliğini kitaplardan değil hayattan alan insan kalbinin

\footnotetext{
${ }^{70}$ SCHOPENHAUER, WWR2, s.594; SCHOPENHAUER, HAS, s.86; G.-V.DER KRONN, s.3; RUGGIERI, s.148.

${ }^{71}$ G.V.DER KROON, s.124.

${ }^{72}$ SCHOPENHAUER, TTF, s.233.

${ }^{73}$ SCHOPENHAUER, TTF, s.235.

${ }^{74}$ USLU, s. 9; ÖKTEM, Niyazi/TÜRKBAĞ, Ahmet Ulvi: Felsefe, Sosyoloj, Hukuk ve Devlet, 1. Bası, Der Kitabevi, İstanbul 2014, s. 69; UYGUN, s. 55.

${ }^{75}$ SCHOPENHAUER, WWR2, s.594; SCHOPENHAUER, HAS, s.86; G.-V.DER KRONN, s.4; RUGGIERI, s.149.

${ }^{76}$ Hobbes'a açık bir gönderme... SCHOPENHAUER, WWR2, s.594; SCHOPENHAUER, HAS s.86; IMAMOĞLU, s.113; VAHAPOĞLU BİNDESEN, s.45.

77 SCHOPENHAUER, WWR1, s.359; SCHOPENHAUER, ITD, s.247; RUGGIERI, s. 145

${ }^{78}$ SCHOPENHAUER, TTF, s.204; VAHAPOĞLU BINDDESEN, s. 120.

${ }^{79}$ SCHOPENHAUER, TTF, s.188,149.

${ }^{80}$ SCHOPENHAUER, TTF, s.194; RUGGIERI, s.146.

${ }^{81}$ SCHOPENHAUER, TTF, s.188, İMAMOĞLU, s.114; VAHAPOĞLU BINNDESEN, s.45.

${ }^{82}$ SCHOPENHAUER, Arthur: Yaşam Bilgeliği Üzerine Aforizmalar (YBÜ), Çev. Mustafa Tüzel, 5. Bası, Türkiye İş Bankası Kültür Yayınları, İstanbul Kasım 2008, s.173.

${ }^{83}$ Schopenhauer'ın temel kitaplarındaki Hobbes atıfları için bkz. SCHOPENHAUER, WWR1, s.38,330,359,368,372; SCHOPENHAUER, WWR2, s.227,233; SCHOPENHAUER, TTF, s. 91,92,172,232.

${ }^{84}$ SCHOPENHAUER, WWR1, s. 372. Aynı doğrultuda bkz. a.g.e., s. 476.

${ }^{85}$ Hobbes'un düşünceleri için bkz. HOBBES, Thomas: Leviathan, Çev. Semih Lim, 13. Bası, Yapı Kredi Yayınları, İstanbul Ocak 2014, s.101; IŞIKTAÇ, s. 144; ÖKTEM/TÜRKBAŞ, s.438; UYGUN, s.72-73.

${ }^{86}$ SCHOPENHAUER, HAS, s. 65.

${ }^{87}$ SCHOPENHAUER, TTF, s. 32.
} 
derin bilicisi”, “önyargının düşmanı”, “doğanın ögrencisi”, "doğanın sıkıcı olmadan ahlak yapabilme yeteneğini bahşettiği yegâne kişi”" sıfatlarıla tanımlamaktadır ${ }^{88}$.

Schopenhauer'ın düşünceleri bir yönüyle de Locke'u hatırlatmaktadır. Özellikle devletin bir "koruma kurumu" olarak tanımlanması ve devlete yalnızca "güvenlik/jandarma" rolü verilmiş olması Locke'a ait bir düşüncedir ${ }^{89}$. Filozof bunun dışında da hukukî normların ceza veya ödülle desteklenmesinin gerekliliği gibi pek çok hususta Locke'a atıfta bulunmaktadır ${ }^{90}$.

Filozofa göre devletin bir diğer amac1 "iç koruma"dır". İnsanlar her ne kadar bencil olsalar da devlet tarafından bir düzen içerisine sokulmuşlardır. Schopenhauer'a göre devletin bir amacı da bu eşitlik halinin devamını sağlayarak insanların bencilliklerinin ortaya çıkmasını engellemektir ${ }^{92}$. Devletin koymuş olduğu kanunlarla acılar eşitlenerek homojen bir dağılım gösterecek böylece olabildiğince minimalize edilecektir ${ }^{93}$.

Devlet, son olarak, vatandaşların hakkını kendisine karşı da korumalıdır ${ }^{94}$. İnsanların bitmek bilmeyen arzulara sahip olduğunu düşünen Schopenhauer'a göre bu korumanın yolu devlet başkanının arzularının tatmin olmasından geçmektedir. Devlet başkanı öylesine tatmin olmuş olmalıdır ki, artık insanlara gıpta edeceği ve insanlardan korkacağ bir şey olmasin ${ }^{95}$. Bu sebeple Schopenhauer'a göre monarşi büyük bir değere sahiptir ${ }^{96}$. Halk kendi çıkarını tespit etmekten uzaktır, bu sebeple demokratik sistemlerde halk demagogların eline düşmekten kurtulamaz ${ }^{97}$. Hükümdar halkın tecessüm etmiş hâlidirr ${ }^{98}$.

Tüm bu amaçlar Schopenhauer'a göre "koruma amacı"nın görünümleridir". Devletin kişinin şahsî haklarını ve mülkiyetini korumayı üstlenmesiyle birlikte doğal bir hak olan ihkak-1 hak ortadan kalkmış, düzen kurulmuş olacaktır ${ }^{100}$. Devletin asli vazifesi bu koruma ödevleridir. Devlet söz konusu koruma amacı dışında bir amaca yönelirse koruma amacını tehlikeye atması anlamına gelir. Bu nedenle devletin başkaca bir amacı olmamalıdır ${ }^{101}$.

\section{B. Schopenhauer'da Ceza Adaleti}

Schopenhauer'ın genel felsefî düşüncesine göre, bireysellik ilkesinin bir gereği olarak insanlar bencildir. Bu bencilliği sınırlamak için kimi kurumlar var olmuştur. Bu kurumların başında elbette din ve ahlak gelir. Schopenhauer ahlak ve din gibi kurumların düşük algı seviyesindeki insanlar için bir anlam ifade etmediğini, zira soyut düşünme kabiliyeti düşük olan bu insanların öldükten sonra karşılaşacakları bir ödül veya cezadan etkilenmelerinin mümkün olmadığını düşünmektedir ${ }^{102}$. İnsan karakteri anlık hazzı ileride geleceği meçhul olan bir ceza tehdidinin önüne koymaktadır ${ }^{103}$. Öyleyse bu kişilerin hemen ve "burada" bir tehditle korkutulması gerekir. Ancak bu şekilde aşağ algı seviyesindeki insanların düzene uymaları sağlanabilir. Bir kişi suç işlemeye karar verdiğinde aklına gelecek olan şey yakalanma ihtimali ve alacağı cezadır. Yakalanmayı ve kanunda belirtilen cezaya çarptırılmayı göze alan bir kişiyi artık ahlakın veya dinin durdurması nadiren mümkün olabilir ${ }^{104}$. $\mathrm{O}$ hâlde düzeni sağlayacak olan ahlak veya din değil, ceza hukukudur ${ }^{105}$.

\footnotetext{
${ }^{88}$ SCHOPENHAUER, TTF, s. 232.

${ }^{89}$ LOCKE, John: Yönetim Üzerine İkinci İnceleme, Çev. Fahri Bakırcı, 3. Baskı, Ebabil Yayınları, Ankara 2016, s. 155-156; IŞIKTAÇ, s. 159; ÖKTEM/TÜRKBAĞ, s. 175; UYGUN, s. 15.

${ }^{90}$ SCHOPENHAUER, TTF, s. 128. Schopenhauer'ın temel kitaplarındaki Locke atıflar1; SCHOPENHAUER, WWR1, s.61,444,445,475,503,504,505,551; SCHOPENHAUER, WWR2, $\quad$ s.10,12,19,20,21,40,41,82,193,272,285, $302,313,582,585,645$; SCHOPENHAUER, TTF, s.21,22,74,99,128,153.

${ }^{91}$ SCHOPENHAUER, WWR2, s.594; SCHOPENHAUER, HAS, s.86; G.V.DER KROON s.124; RUGGIERI, s.149.

${ }^{2}$ SCHOPENHAUER, Arthur: Din Üzerine (DİN), Çev. Ahmet Aydoğan, 2. Bası, Say Yayınları, İstanbul 2011, s.15; VAHAPOĞLU BİNDESEN, s.45.

${ }^{93}$ G.V.DER KROON, s.124.

${ }^{94}$ SCHOPENHAUER, WWR2 s.595; SCHOPENHAUER, HAS, s.86; G.V.DER KROON s.124, RUGGIERI, s.149.

${ }^{95}$ ÇALIŞKAN AKÇETIN, s.85.

${ }^{96}$ SCHOPENHAUER, WWR2 595, SCHOPENHAUER, HAS, s.87; RUGGIERI, s.148.

${ }^{97}$ SCHOPENHAUER, PVP, $\$ 126$.

${ }^{98}$ SCHOPENHAUER, PVP, $\$ 127$.

${ }^{99}$ ÇALIŞKAN AKÇETIN, s.80.

${ }^{100}$ SCHOPENHAUER, YBÜ, s.83.

${ }^{101}$ SCHOPENHAUER, WWR2, s.596, SCHOPENHAUER, HAS, s.87; ÇALIŞKAN AKÇETİN, s.81.

102 İMAMOĞLU, s.51.

103 Ünlü mafya lideri AlCapono'ya izafe edilen ünlü bir hikâye vardır: Çocukluğunda bisiklete sahip olmak isteyen AlCapono Tanrı'ya çok dua etmiş fakat bir bisikleti olmamıştır. Sonra Tanrı'nın çalışma metodunun bu olmadığını fark ederek bir bisiklet çalmış ve her gece Tanrı'ya kendisini affetmesi için dua etmeye başlamış.

104 SCHOPENHAUER, TTF, s.275. SCHOPENHAUER, DİN s.105'te de Schopenhauer "Bir Diyalog" bu ifadeleri Philalethes'e söyleterek kendi düşüncelerini ifade etmektedir.

105 IMAMOĞLU, s.67.
} 


\section{Cezanın Amacı}

Schopenhauer'a göre cezalandırmanın amacının ıslah olduğu düşüncesi sorunlu bir yaklaşımdır. Eğitim bir iyilikken ceza kötülüktür. Cezalandırmayla bir insana hem iyilik hem de kötülük yapılması mümkün değildir. Hapishanelerin birer eğitim kurumu olduğu düşünülecek olursa, buralara girebilmenin suç işlemekle mümkün olmasını Schopenhauer "üzüntü verici" olarak nitelendirmiştir ${ }^{106}$. Bunun yanında suçların nedeni çoğunlukla eğitimsizlik değil, ahlakî karakterdir. Ahlakî karakter doğuştandır ve değiştirilmesi mümkün değildir ${ }^{107}$. Ahlaksız kimselerin zorlamayla ahlaklı kişiler hâline geleceklerine inanmak Schopenhauer'a göre meşe ağacının zorlamayla kayısı meyvesi vereceğine inanmaktan ya da kurşunun baskıyla altına dönmesini beklemekten farksızdır ${ }^{108}$.

$\mathrm{Bu}$ gerekçelerle Schopenhauer cezanın caydırıcılığı üzerinde durmuştur. Ona göre cezanın asıl amacı caydırıcılıktır. Hukuk, cezalar aracılı̆̆ıyla insanları yasak fiillerden caydırır ${ }^{109}$. Böylece kötü ve suça mütemayil karakterli müstakbel suçlu ceza korkusuyla suçu işlemekten kaçınacaktır. İnsan iradesi özgür değildir. İnsan fiillerini yönlendiren muharrik istemenin dayattı̆̆ı arzulardır. Arzuların zorlamasıyla insanlar suça sürüklenmektedir ${ }^{110}$. Öyleyse eğiterek davranışların değiştirilmesi mümkün değildir. Ancak arzular (güdü/motif) etkilenerek insan davranışlarına yön verilebilir. Ceza da arzuları etkileyerek caydırıcılık fonksiyonuyla doğrudan kişilerin acıdan kaçan hazza koşan egosuna tesir etmekte, böylece fiili karşılığında cezalandırılacağını gören failin güdülenmesini mümkün kılmaktadır ${ }^{11}$. İrade hürriyetinin mevcut olmaması kişileri cezalandırmaya engel değildir. Zira bu ceza tehdidi dolayısıyla yukarıda sayılan sebeplerle olası suçluların arzuları etkilenerek suç işlemekten cayacaklardır"112. O hâlde ceza kanunlarını bir çeşit "suç eylemlerine karşı güdüler kataloğu" olarak ifade edilebilir ${ }^{113}$.

Schopenhauer cezaların kefaret olduğu düşüncesine de karşı çıkmaktadır. Böyle bir ceza yalnız bir intikamdan ibarettir. Halbuki Schopenhauer'a göre intikam kötü bir ruh hâlinin tezahürüdür ${ }^{114}$. Çünkü intikam ve öç duygularına sahip bir kişi kötülüğe kötülükle karşılık vermektedir. Böyle bir kişi için ceza amaçtır. Kişi hiçbir faydası olmadığ 1 hâlde faile işkence ederek bundan zevk alır ${ }^{115}$. Schopenhauer varisi olarak gördüğü Kant'in kefaret düşüncesine de şiddetle karşı çikar ve "böyle bir ögreti Kant'a ait olsa bile saçma, anlamsız ve tamamen haksızdır" diyerek bir insanın diğer bir insanı yargılamasına ve günahları uğruna ona eziyet etmesine anlam veremediğini dile getirmektedir ${ }^{116}$.

Schopenhauer'ın caydırıcılık üzerine düşünceleri onun teşebbüse ilişkin yaklaşımını da belirlemiştir. Cezaların amacı intikam almak değil, cezalandırmaktır. O hâlde teşebbüs aşamasında kalan eylemler de cezalandırılmalıdır. Neticenin gerçekleşip gerçekleşmemesi kefaret açısından önem arz edebilir. Ancak şayet olası faillerin suç fiilinden uzak durması isteniyorsa, suça giden yolun önceden kesilmesi adına suça yönelik girişimi ifade etmekte olan teşebbüs de cezalandırılmalıdır ${ }^{117}$.

Tüm bu gerekçelerle Schopenhauer'a göre ceza hukukunun "fail ceza hukuku" değil, "fiil ceza hukuku" olması gerekir ${ }^{118}$. Mücadele edilmesi gereken failin şahsı değil, işlediği fiildir. Fail, yukarıda da ifade edildiği üzere, karakterinin değiştirilmesi mümkün olmayan bir yapıya sahiptir. Ancak fiilin cezalandırılması olası benzer fiiller için caydırıcı olabilir. Diğer bir deyişle Schopenhauer'a göre hukuk düzeninin mücadelesinin öznesi fail değil, failin haksızlık içeriğine sahip fiilidir.

\section{Orant1lilik}

Schopenhauer, suç ve ceza arasında bir orantı olması gerektiğini savunur. Suç ve ceza arasındaki orantı belirlenirken cezalandırmak suretiyle önlenecek zarar ya da haksızlığın büyüklüğüyle kişiyi suça zorlayan güdünün zorlayıcılı̆ğ da hesaba katılmalıdır. Örneğin o dönem Polonya kanunlarında yer alan

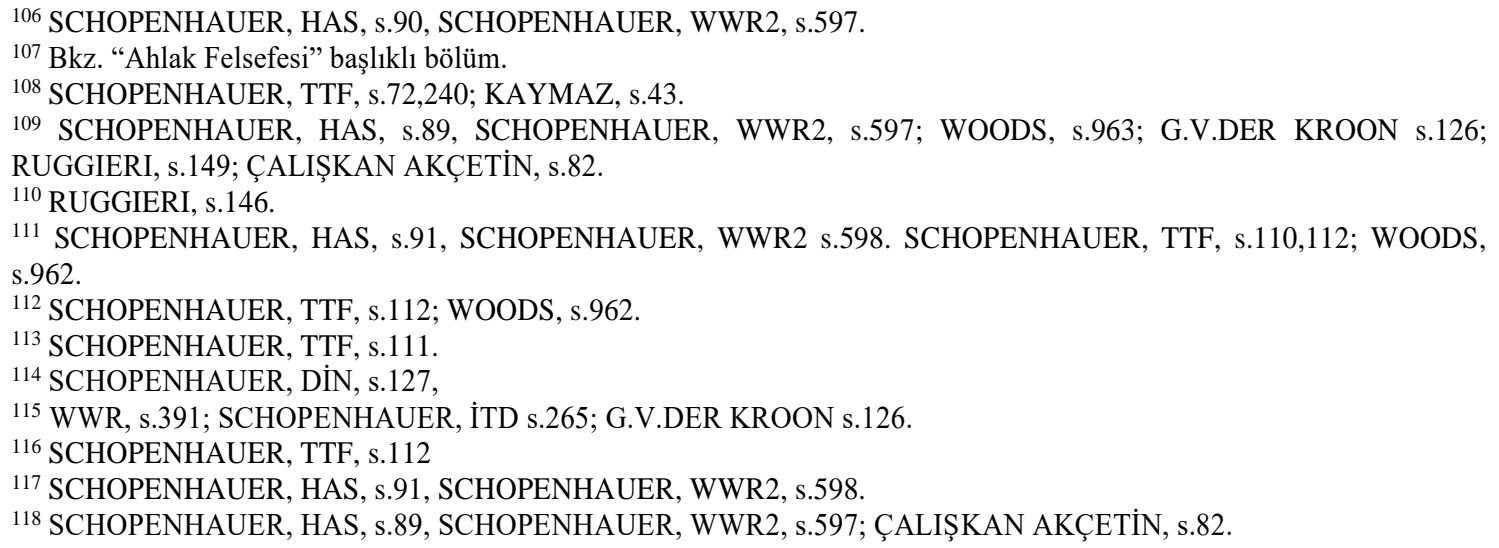


yaban öküzü öldürmenin karş1lığı olarak idam cezası verilmesi Schopenhauer'a göre orantısız bir cezadır. "Yaban öküzü türünün korunması insan hayatıyla satın alınamaz"119.

Herkesin herkesle yaptığı bir sözleşmeyle toplumsal yaşam kurulmuştur. Bu sözleşme gereğince güvenlik ve barış için herkes canını teminat göstermiş, karşılığında da herkesin canını teminat olarak almıştır. Bu hâlde Schopenhauer'a göre ceza bir boyutuyla da rehine benzemektedir. Nasıl ki özel hukuk ilişkilerinde sözleşmeye aykırılık hâlinde alacaklı rehin vasıtasıyla orantılılık şartı da dikkate alınarak alacağını tatmin edebiliyorsa, ceza verilirken de failin rehin olan canına -yine ölçülülük kaydıyla- başvurulabilecektir. Yurttaşların hayatlarını güven içinde hissedebilmeleri için canlarının karşıllı̆ı olarak can teminatını elinde bulundurmaları, diğer bir tabirle idam cezası mevcut olmalıdır ${ }^{120}$. Filozofa göre idam cezalarının kaldırılmasını istemek hatalı bir yaklaşımdır. Zira idam cezalarının sebebi cinayet suçudur. Filozof bu noktada tersten bir akıl yürütme yaparak idam cezalarının kaldırılması isteniyorsa evvela cinayetlerin sonlandırılması gerektiğini söyler ${ }^{121}$.

Yine Schopenhauer ilginç bir şekilde bedensel cezaların kaldırılmasına karşı çıkmaktadır. Filozofa göre dünyada onca felaket varken bedensel cezaların bir felaket olarak gösterilmesi doğru değildir. Mülk sahibi olmadığı için mülkü elinden alınamayacak, özgürlüğünden alıkoymanın da faydadan çok zarar getireceği kişiler söz konusu olduğunda bu kişileri dayakla cezalandırmak ucuz ve doğal bir yöntem olacaktır. Schopenhauer'a göre kırbaçlama cezası da oldukça uygun bir cezalandırma yöntemidir ${ }^{122}$. Filozof, bedensel cezalara karşı çıkılırken "insan haysiyetine" dayanılmasını "kınayarak" bunları boş sözler olarak nitelemektedir ${ }^{123}$. Schopenhauer "demokrasi", "insan hakları" ve "hukukun üstünlügü̈" gibi kavramların çağının "trinite sacres"i olduğunu, gizli emellerin aleti olarak kullanılan bu kavramların artık kimseye inandırıcı gelmeyen "martavallar" olduğun düşünmektedir ${ }^{124}$.

Bedensel cezaları savunan filozof iş hücre ve kapatılma cezası gibi tecrit cezalarını geldiğinde bu cezaları sert bir şekilde eleştirmektedir. Schopenhauer'a göre Amerikan ceza sistemi suçlunun karakterini ve kalbini geliştirmeyi hedef almaz. Zaten kişinin karakterinin değiş̧irilmesi mümkün değildir. Buna karşın Amerikan ceza sistemi kişilere ahlaklı ve hukuka saygılı bir birey olmanın daha kolay ve bireysel çıar açısından faydalı bir yol olduğunu göstererek suçluları hukuk kurallarına saygılı bireyler hâline getirmeye çalışı1' ${ }^{125}$.

Bununla birlikte Philadelpia'nın katı cezalandırma sisteminde mahkumların tecrit edilmesi suretiyle "can sıkıntısı" bir cezalandırılma metodu olarak kullanılır. Philadelpia'nın katı cezalandırma sisteminde mahkûmların can sıkıntısına terk edilmiş olması Schopenhauer'a göre korkunçtur ${ }^{126}$. Filozof böylesine ağır bir cezalandırmanın mahkûmların intihar etmesine sebebiyet verdiğini yazar ${ }^{127}$.

Mahkûmun tecridi anlamına gelen hücre cezası başarısız bir cezadır. Zira her şeyden önce caydırıcılık amacını sağlayamamaktadır. Bu cezayı yalnızca çeken bilir, öyleyse böyle bir ceza müstakbel failler için caydırıcı olamaz ${ }^{128}$. Diğer taraftan böyle bir cezalandırma göründüğünden çok daha korkunçtur. Dolayısıyla hücre hapsi cezanın biricik amacı olan caydırıcılığı sağlamakta yetersiz olduğu hâlde insanlara gereğinden fazla istırap veren bir sistemdir ${ }^{129}$.

${ }^{119}$ SCHOPENHAUER, HAS, s.90-91; SCHOPENHAUER, WWR2, s.598.

${ }^{120}$ SCHOPENHAUER, HAS, s.90; SCHOPENHAUER, WWR2, s.598.

${ }^{121}$ SCHOPENHAUER, HAS, s.90; SCHOPENHAUER, WWR2, s.598.

122 Filozofun bugünün hâkim ceza hukuku paradigması bakımından kabul edilemez olan bu fikirleri kendi zamansallığı içerisinde ele alınmalıdır. 18. yüzyılda yaşamış olan filozof için bedensel cezaların kaldırılması tartışmaları henüz yeni tartışmalardır. Modern ceza hukukunun yeni doğmaya başladığı bir tarihî dönem içerisinde yaşamış filozof bu fikirlerinden dolayı kınanmamalıdır.

${ }^{123}$ SCHOPENHAUER, YBÜ s.89, SCHOPENHAUER, DİN, s.138.

${ }^{124}$ SCHOPENHAUER, YBÜ, s.13.

${ }^{125}$ SCHOPENHAUER, TTF, s.71, 240; benzer yönde ÇALIŞKAN AKÇETIN, s. 82.

126 "Can sıkıntısı" kavramının Schopenhauer düşüncesindeki önemi için "Varlık Felsefesi” başlığına bakınız.

${ }^{127}$ SCHOPENHAUER, İTD s.233; SCHOPENHAUER, WWR1, s.340

${ }^{128}$ SCHOPENHAUER, HAS, s.90, SCHOPENHAUER, WWR2 s.597; WOODS, s.963.

${ }^{129}$ WOODS, s.963. Ülkemizde özellikle 20'nci yüzyılın sonlarıyla 21'inci yüzyılın başları ceza infaz kurumu tartışmalarıyla geçmiştir. Koğuş sistemi hapishanelerde terör örgütlerinin hâkimiyeti ve devletin hapishanelerde hâkimiyeti sağlayamamas1 koğuş sisteminin terk edilerek F tipi ceza infaz kurumu sistemine geçilmesi sonucunu doğurmuştur(PARLAK, Cansu: Türkiye'de Siyasal Hayat ve Cezaevleri: Hayata Dönüş Operasyonları Üzerine Bir İnceleme, Hacettepe Üniversitesi Sosyal Bilimler Enstitüsü, Yayımlanmamış Yüksek Lisans Tezi, Ankara, 2018, s.58). Bu amaçla yapılan Hayata Dönüş Operasyonları ve bu operasyonlardaki can kayıpları kamuoyunun gündemini uzun süre meşgul etmiştir(PARLAK, s.58 vd.). Yine koğuş sisteminin yerine ikame edilen ve genellikle terör örgütü mensuplarının cezalarının infaz edildiği F tipi yüksek güvenlikli ceza infaz kurumlarındaki sistemin insaniliği, temel hak ve hürriyetler açısından değeri gerek siyasal düzlemde, gerekse hukukçular arasında bir tartışma konusu hâline gelmiştir(PARLAK, s.61). Söz konusu tartışmalar çeşitli zamanlarda hukukçuların gündemine gelmektedir(BACAKSIZ, Pınar: "Cezalandırma ve Topluma Yeniden Kazandırma”, Dokuz Eylül Üniversitesi Hukuk Fakültesi Dergisi, 16(Prof. Dr. Hakan PEKCANITEZ’e Armağan Özel Sayıs1), 2015, s.4935). Yabanc1 


\section{Schopenhauer'ın Ceza Adaleti Yaklaşımının Değerlendirilmesi}

Schopenhauer'ın ceza adaleti yaklaşımı ele alınmadan evvel Schopenhauer için cezalandırıcı bir adalet anlayışının tali, hatta "baş aşağı bir adalet"in temsili olduğu hatırlanmalıdır ${ }^{130}$. Schopenhauer'ın ceza adaleti yaklaşımı incelendiğinde düşüncelerinin cezanın "caydırıc1lık" amacı temelinde şekillendiği görülmektedir. Ceza teorileri arasında caydırıcılık fonksiyonu üzerinde duran teori Sosyal Fayda Teorisi'dir. Sosyal Fayda Teorisi, bir Klasik Okul teorisi olup diğer Klasik Okul düşüncesi olan Mutlak Adalet Teorisi gibi ceza sorumluluğunun temelini kusur ilkesine dayandırmaktadır. Klasik Okul düşüncesine göre insanlar irade hürriyetine sahiptirler ve iradî olarak işledikleri fiillerin sorumluluğuna da katlanmaları gerekir ${ }^{131}$. Bununla birlikte Klasik Okul teorilerinden Kant'in savunmakta olduğu Mutlak Adalet Teorisi'ne göre cezalandırmada fayda güdülmemesi ve suç işleyen bir kişiye pratik aklın saf koşulsuz buyruğu olarak ceza uygulanması gerekirken, Sosyal Fayda Teorisi düşünürlerine göreyse cezalandırmanın meşru olabilmesi için fayda sağlaması gerekir. Cezalardan toplumsal bir fayda elde edilebilmesiyse cezaların infazında iki amaç gütmeyi gerektirir: Genel önleme (caydırıcılık) ve özel önleme (1slah) ${ }^{132}$.

Her ne kadar Schopenhauer'da cezalandırmanın amacı caydırıcılık olsa da filozofa göre insanlarda özgür irade mevcut değildir; insan karakteri doğuştan ve değiştirilmezdir ${ }^{133}$. Schopenhauer'ın caydırıcılık düşüncesinin irade hürriyetine değil de, güdülere dayanıyor olması filozofun Sosyal Fayda Teorisi'nden ilk ayrımıdır. Bununla birlikte filozofun Sosyal Fayda Teorisi'nden esas ayrımı karakterin değiştirilemezliği düşüncesiyle birlikte cezanın ıslah fonksiyonunun reddedilmesinde ortaya çıkmaktadır. Öyleyse Schopenhauer'ın Sosyal Fayda Teorisi düşüncesinden ayrıştığ 1 ifade edilmelidir.

İnsan özgürlüğünü reddeden filozofun görüşleri pek çok noktada Biyolojik Teori ${ }^{134}$ yaklaşımına yakın bir anlayış arz etmektedir. Biyolojik Teori felsefî pozitivizm üzerine inşa edilmiş bir yaklaşımdır. Pozitivist felsefe geleneğine uygun olarak irade hürriyetini reddeden Biyolojik Teori, determinist bir düşünce benimseyerek insan fiillerini diğer doğa olaylarıyla aynı gözle incelemiştir. Bu düşünceye göre insanı suça yönelten ahlakî kötülük ve iradî fiiller değil; kişinin biyolojik, sosyolojik ve psikolojik özellikleridir ${ }^{135}$. Biyolojik teori bu fikirleri doğrultusunda "doğuştan suçluluk" kavramını üretmiştir ${ }^{136}$. Fiillerinde özgür olmayan insanların ceza sorumluluğunun temelinde ahlakî kötülük olmadığından, kötülüğün ödettirilmesi anlamında kefaret ceza sorumluluğunun temeli olamaz. Bunun yanında Sosyal Fayda Teorisi müellifleri yanlış bir amaç benimsemiş olup cezalandırılarak ıslah edilmeleri veya ceza ile olası faillerin cezadan korkarak suç işlemekten vazgeçmeleri insanlar özgür iradeye sahip olmadıklarından mümkün değildir ${ }^{137}$. Bu sebeple Biyolojik Teori ceza sorumluluğunun esasını toplumsal tehlikelilikte aramaktadır ${ }^{138}$. Fail suçun sorumlusu değildir, ancak suç işlemeye meyyal bir metabolizmaya sahiptir. Öyleyse toplum failden korunmalıdır. Bunun yolu da cezalandırma değil, tedavidir ${ }^{139}$.

Schopenhauer'ın düşüncesini Biyolojik Teori'yle mukayese ettiğimizdeyse her şeyden önce filozofun karakterin değişmezliği ve dolayısıyla suça yönelimin doğuştan olduğu fikri bize Biyolojik Teori düşüncesiyle paralellik göstermektedir. Ancak Biyolojik Teori’ye göre -Schopenhauer'dan farkl1

\footnotetext{
literatürde tecrit sistemi incelenirken Schopenhauer'a atıflar yapılmakta, Schopenhauer'ın eleştirileri değerlendirilmektedir . Ülkemizde de önemli bir tartışma konusu olan ve güncelliğini koruyan tecrit sistemi ve F tipi yüksek güvenlikli ceza infaz kurumlarının insaniliğinin değerlendirilmesinde Schopenhauer'ın fikirlerinin ufuk açıcı olacağı kanaatindeyiz. (Schopenhauer'in "can sıkıntısı" kavramı ile "hücre cezası" üzerine yapılan tartı̧̧alara örnek olması adına bkz. WOODS, s.959-978).

${ }^{130}$ Filozofun fikirleri hatırlanacak olursa, filozofa göre ebedi-adalette ceza söz konusu olamaz. Adaletsizlik ve kötülük tasavvura aittir. Tasavvurdaki bu kötülüğün minimize edilmesi, toplumsal düzenin sağlanması için ceza bir araç olarak mevcuttur.

131 ÖZBEK, Veli Özer/DOĞAN, Koray/BACAKSIZ, Pınar: Türk Ceza Hukuku Genel Hükümler, 11.Baskı, Seçkin Yayınları, Ankara 2020, s.102.

132 DÖNMEZER, Sulhi/ERMAN, Sahir: Nazarî ve Tatbikî Ceza Hukuku Genel Kısım, Sulhi Garan Matbaası Vârisleri Koll. Şti., 5.Basım, İstanbul 1973, s.101.

${ }^{133}$ Filozofun karakterin değiştirilemezliği ve irade hürriyetinin reddine ilişkin görüşlerini hatırlamak için I.C.2. Ahlak Felsefesi başlıklı bölüme bakınız.

${ }^{134}$ Biz doktrinde "Pozitivist Teori” olarak da ifade edilen bu teoriyi "Biyolojik Teori” olarak ifade etmeyi tercih ettik. Böylece karışma ihtimali bulunan Hukukî Pozitivizmle ayırt etmek istedik. Biyolojik teori felsefî (ontolojik) anlamda bir pozitivizmi ifade etmekte olup suçluluğun temellerini insan metabolizmasında ve pozitif etmenlerde aramaktadır.

135 ÖZBEK/DOĞAN/BACAKSIZ, s.103.

136 ÖZBEK/DOĞAN/BACAKSIZ, s.104.

${ }^{137}$ TANER, Tahir: Ceza Hukuku Umumî Kısım, İstanbul Üniversitesi Yayımları, 3. Basım, İstanbul 1953, s.59.

138 DÖNMEZER/ERMAN, s.75,84; ÖZBEK/DOĞAN/BACAKSIZ, s.104.

139 ÖZBEK/DOĞAN/BACAKSIZ, s.103.
} 
olarak- cezanın amaçlarından bir tanesi doğuştan suçlu olan kimselerin tedavi edilerek anti-sosyal kişiliklerinin ortadan kaldırılmasıdır. Cezanın amacı caydırmak vasıtasıyla müstakbel suçluları güdülemek ve suçların önüne geçmek olduğundan Schopenhauer Biyolojik Okul düşüncesinden de ayrilmaktadır ${ }^{140}$.

\section{SONUÇ VE ÖNERILER}

Çalışmamızda filozof Schopenhauer'ın hukuk felsefesi ve ceza adaleti yaklaşımı incelenmiştir. Çalışma kapsamında öncelikle filozofun kendisini varisi olarak takdim ettiği Immanuel Kant'ın fikirlerine kısaca değinilmiş ve Schopenhauer'un genel felsefesi tanıtılmıştır. Daha sonra filozofun hukuk felsefesi incelenmiştir. Böylece filozofun bizce hukuk felsefesi açısından dikkate değer olan fikirlerine dikkat çekilmeye çalışılmıştır.

Çalışmamızın ilk bölümünde Schopenhauer'ın varlık felsefesi ve ahlakî yaklaşımı incelenmiştir. $\mathrm{Bu}$ bölümde filozofun isteme ve tasarım kavramları açıklanmıştır. Görülmüştür ki filozofa göre kendinde-şey olan isteme, fenomenler dünyasını ifade etmekte olan tasavvuratta arzular aracılı̆̆ıyla insanı bencil ve egoist yapar. Halbuki istemede ben ve öteki aynıdır. İnsan karakteri değişmezdir, dahası insan kendi karakterine de yabancıdır. Bu sebeple insanda olduğu sanılan irade hürriyeti bir yanılmadan ibarettir, iradeye sahip olan tek varlık kendinde şey olan istemedir. Ancak istemenin iradesi de kördür.

Hukuk felsefesi ve ceza adaleti yaklaşımını bu ontolojik ve ahlakî zemin üzerine kuran filozof hak, adalet, devlet gibi temel hukukî kurumları incelemiştir. Filozofa göre menfi bir anlam taşıyıp "haksızlık etmemek" şeklinde tanımlanabilecek olan hak kavramı devletlerden önce de vardır. Devletler hakkın kurucusu olarak değil koruyucusu olarak ortaya çıkmışlardır. Devlet bir sosyal sözleşmenin ürünü olarak ortaya çıkmıştır ve tek maksadı korumayı sağlamaktır. İnsanın egoist bir yapıya sahip olduğunu bu sebeple de Hobbes'un tabiriyle insanın, insanın kurdu olduğunu kabul eden filoza göre devlet insanları diğer insanlardan korur, acıların homojen dağıtımını sağlamak suretiyle eşitliği sağlar ve nihayet insanları kendisinden koruyacak mekanizmaları geliştirir. Hukuk ve devlet haksızlık ve acıların olduğu bir dünyada bir telafi mekanizması olarak ortaya çıkmıştır. Zira tek olan istemede herkes herkesle bir ve bütündür. Böyle bir birlik durumu filozofun düşüncesinde ebedî-adalet olarak anılmıştır. İnsanlar gönüllü olarak bu adalete tâbi olabilirler ki böyle bir adalet filozofun düşüncesinde gönüllü-adalet olarak anılmıştır. Buna karşın tasavvurattaki düzenin sağlanabilmesi için dünyevî bir adalet / hukuk da vardır ki bu nevi bir adaleti filozof zamansal-adalet veya salt yasal doktrin olarak ifade etmektedir. Zamansal-adalet baş aşağı dönmüş, telafi edici bir mekanizmadan ibarettir.

Filozofun ceza adaleti tüm bu yaklaşımlar üzerine oturmaktadır. Zamansal-adalet ancak ceza hukukuyla birlikte sağlanabilir. Özgür iradeye sahip olmayan insanın karakterini değiştirmesi mümkün değildir. Ancak ceza tehdidiyle birlikte güdüler etkilenebilir. Zira bencil bir yapıda olan insan acıdan kaçmakta, hazza yönelmektedir. Cezaların kefaret olduğu yönündeki düşünceler kötü ruh hâlinin bir tezahürü olduğu gibi, ıslah da mümkün olmayan çelişkili bir yaklaşımdır. O hâlde cezalar caydırıcı olmalı, müstakbel suçluları korkutmalıdır. Bu yaklaşımıyla birlikte filozofun cezalandırmanın amacını açıklayan teorilerden Sosyal Fayda Teorisi ve Biyolojik Teori arasında, Biyolojik Teori'ye yakın özgün bir yaklaşım geliştirdiği ifade edebilir. Bununla birlikte haddinden daha ağır / orantısız bir ceza da verilmemelidir. Bu kapsamda hücre hapsi ve tecrit sistemini ele alan filozofa göre bu nevi cezalar bir insan için en korkunç işkence olan can sıkıntısına sebebiyet vermesi hasebiyle orantısız, caydırıcı olmaması açısından da başarısız bir cezadır. Bununla birlikte filozof bedensel cezaların terk edilmeye başlandığı bir çağda bedensel cezaları savunması bakımından da eleştirilebilir bir tutum içerisindedir.

Çalışmamız Schopenhauer'ı Türk doktrinine tanıtmak amacını taşıdığından filozofun hukuk fikirleri olabildiğince çok konuya değinerek betimlenmeye çalışılmıştır. Bu sebeple esasında makalemizin her bir başlığı çok daha kapsamlı müstakil bir çalışmanın konusu olabilir. Söz gelimi hukuk ve devlet anlayışında filozofun fikirlerinin doğal hukukçu bir yaklaşımla açıklanabileceği tespit edilmiştir. Filozofun fikirlerinin doğal hukukla olan bağlantısı daha kapsamlı bir çalışmanın konusu olabilir ${ }^{141}$. Yine filozofun ortaya koymuş olduğu özgün adalet teorisi bizce ayrıntılı bir incelemeyle çalış1labilir. Filozofun devletin kökenine ilişkin sosyal sözleşmeci fikirleri olduğu tespit edilmiştir. Aynı şekilde filozof eserlerinde sosyal sözleşmeci büyük düşünürlerin fikirlerini eleştirerek bu düşünürler arasında adeta bir hakemlik yapmak iddiasındadır. Bu sebeple hem gelecek çalışmalarda

\footnotetext{
140 İlginç olan ise Biyolojik Teori gibi pozitivist ontolojinin bir ürünü olan yaklaşımla Schopenhauer gibi idealist olarak ifade edilebilecek filozof arasında böylesine benzerliklerin mevcut olmasıdır. İlk bakışta çelişki gibi görünen bu benzerliğin temelinde Schopenhauer'ın özgürlüğü insana değil istence hasretmesinde bulmak mümkündür.

${ }^{141}$ Krş. G.-V.DER KRONN, s.11-15. MARCIN, s.814 vd.
} 
filozofun sosyal sözleşmeci yaklaşımı ayrıntılı olarak incelenebilir, hem de sosyal sözleşmeci düşünürler açımlanırken Schopenhauer'ın eleştirilerinden yararlanılabilir. Çalışmamızın içinde de ifade ettiğimiz üzere filozofun fikirleri özellikle hücre hapsi ve tecrit sistemine ilişkin tartışmalarda yol gösterici niteliktedir. Bu sebeple salt filozofun bu noktadaki yaklaşımına odaklanan psikoloji biliminin verileri de göz önüne alınarak multidisipliner bir çalışma yapılabilir. Hakeza filozofun ceza hukuku ve ceza-adaleti fikirleri özgün bir yaklaşım ortaya koymakta olup bizce Türk doktrini filozofun fikirlerinden istifade edebilir. Tüm bunların yanında bu çalışma bir hukukçu tarafindan kaleme alınmıştır. Felsefe araştırmacılarının bu çalışmada kendi disiplinlerinin bakış açılarıyla pek çok eksik bulmaları pek mümkündür. Bu sebeple gelecekte felsefe alanında Schopenhauer üzerine yapılacak çalışmalarda Schopenhauer'ın hukuk fikirlerine de mutlaka yer verilerek bu fikirler felsefe akademisin kavram ve bakışılla da incelenmelidir.

\section{KAYNAKÇA}

ARSLAN, Ahmet: Arthur Schopenhauer'un Ahlak Felsefesi ve Pesimizm, Dokuz Eylül Üniversitesi Ssyal Bilimler Enstitüsü, Yayımlanmamış Yüksek Lisans Tezi, İzmir, 2019.

ATAYMAN, Veysel: Varolmanın Acısı: Schopenhauer Felsefesine Giriş, 1. Bası, Donkişot Yayınları, İstanbul 2004.

AYDOĞDU, Ahmet: Schopenhauer, 1. Bası, Say Yayınları, İstanbul 2009.

BACAKSIZ, Pınar: "Cezalandırma ve Topluma Yeniden Kazandırma", Dokuz Eylül Üniversitesi Hukuk Fakültesi Dergisi, 16 (Prof.Dr.Hakan PEKCANITEZ'e Armağan Özel Sayıs1), 2015, s. 4917-4941.

CAF, Bahar: Arthur Schopenhauer'da Pesimizmin Felsefesi, Van Yüzüncü Y1l Üniversitesi Sosyal Bilimler Enstitüsü, Yayımlanmamış Yüksek Lisans Tezi, Van, 2019.

CARTWRIGHT, David E.: Schopenhauer, Çev. Sibel Erduman, 1. Bası, Türkiye İş Bankası Kültür Yayınları, İstanbul Nisan 2014.

ÇALIŞKAN AKÇETiN, Nurhayat: "Merhamet ve Devlet: Schopenhauer", Felsefe ve Sosyal Bilimler Dergisi, (21), 2016, s.71-86.

DÖNMEZER, Sulhi/ERMAN, Sahir, Nazarî ve Tatbikî Ceza Hukuku Genel Kısım, Sulhi Garan Matbaası Vârisleri Koll. Şti., 5. Basım, İstanbul 1973, s. 101.

GODART-VAN DER KROON, Annette: "A. Schopenhauer's theory of justice and its implication to natural law", Jahrbuch der Schopenhauer-Gesellschaft 2003, 84(-), 2003, s.121-145.

GÜRIZZ, Adnan: Hukuk Felsefesi, 13. Bası, Siyasal Kitabevi, Ankara 2018.

HEIMSOETH, Heinz: Kant'ın Felsefesi, Çev. Takiyettin Mengüşoğlu, 6. Bası, Doğu Batı Yayınları, Ankara Haziran 2014.

HOBBES, Thomas: Leviathan, Çev. Semih Lim, 13. Bası, Yapı Kredi Yayınları, İstanbul Ocak 2014.

IŞIKTAÇ, Yasemin: Hukuk Felsefesi, 6. Bası, Filiz Kitabevi, İstanbul Kasım 2019.

İMAMOĞLU, Kıymet Tuğba: Arthur Schopenhauer'da Metafizik Kötülük ve Varoluşun Verdiği Acıdan Kaçış Olarak Ahlaki Eylemler, İstanbul Medeniyet Üniversitesi Sosyal Bilimler Enstitüsü, Yayımlanmamış Yüksek Lisans Tezi, İstanbul, 2019.

KAYMAZ, Murat: Schopenhauer Felsefesinde Ahlakın Anlamı, Bahçeşehir Üniversitesi Sosyal Bilimler Enstitüsü, Yayımlanmamı̧ Yüksek Lisans Tezi, İstanbul, 2018.

LOCKE, John: Yönetim Üzerine İkinci İnceleme, Çev. Fahri Bakırcı, 3. Baskı, Ebabil Yayınları, Ankara 2016.

MARCIN, Raymond B.: "Schopenhauer's Theory of Justice", Catholic University Law Review., 43(3), 1994, s.813-865.

ÖKTEM, Niyazi/TÜRKBAĞ, Ahmet Ulvi: Felsefe, Sosyoloj, Hukuk ve Devlet, 1. Bası, Der Kitabevi, İstanbul 2014.

ÖZBEK, Veli Özer/DOĞAN, Koray/BACAKSIZ, Pınar: Türk Ceza Hukuku Genel Hükümler, 11. Baskı, Seçkin Yayınlar1, Ankara 2020, s. 102.

PARLAK, Cansu: Türkiye'de Siyasal Hayat ve Cezaevleri: Hayata Dönüş Operasyonları Üzerine Bir İnceleme, Hacettepe Üniversitesi Sosyal Bilimler Enstitüsü, Yayımlanmamış Yüksek Lisans Tezi, Ankara, 2018.

RUGGIERI, Davide: "The metaphysics of conlict: some reflections on Schopenhauer's politics", Voluntas Revista Internacional de Filosofia, 7(1), 2016, s.140-154.

SCHOPENHAUER, Arthur: Din Üzerine (DIN), Çev. Ahmet Aydoğan, 2. Bası, Say Yayınları, İstanbul 2011.

SCHOPENHAUER, Arthur: Felsefe Tarihinden Kesitler (FTK), Çev. Ahmet Aydoğan, 1. Bası, Say Yayınları, İstanbul 2014.

SCHOPENHAUER, Arthur: Hukuk, Ahlak ve Siyaset Üzerine (HAS), Çev. Ahmet Aydoğan, 1. Bası, Say Yayınları, İstanbul 2009.

SCHOPENHAUER, Arthur: İsteme ve Tasarım Olarak Dünya (İTD), Çev. Levent Özşar, 2. Bası, Biblos Kitabevi, İstanbul 2009.

SCHOPENHAUER, Arthur: Okumak, Yazmak ve Yaşamak Üzerine (OYY), Çev. Ahmet Aydoğan, 2. Bası, Say Yayınları, İstanbul 2008. 
SCHOPENHAUER, Arthur: Parerga ve Paralipomena Cilt II (PVP), çev. Gürkan Başay/Murat Kaymaz, 1. Bask1, Otüken Neşriyat, İstanbul 2021.

SCHOPENHAUER, Arthur: The Two Fundamental Problems of Ethics (TTF), Trans. Christopher Janaway, 1. Press, Cambridge University Press, Cambridge 2009.

SCHOPENHAUER, Arthur: The World as Will and Representation v. I (WWR1), Trans. Christopher Janaway, 1. Press, Cambridge University Press, Cambridge 2010.

SCHOPENHAUER, Arthur: The World as Will and Representation v. II (WWR2), Trans. E. F. J. Payne, 1. Press, Dover Publications, Inc., New York 1966.

SCHOPENHAUER, Arthur: Yaşam Bilgeliği Üzerine Aforizmalar (YBÜ), Çev. Mustafa Tüzel, 5. Bası, Türkiye İş Bankası Kültür Yayınları, İstanbul Kasım 2008.

SHINER, Roger A.: "Philosophy of Law", in Alston, William P. vd. (ed.), The Cambridge Dictionary of Philosophy, Cambridge Universtiy Press, New York 1999, s. 676-677.

TANER, Tahir, Ceza Hukuku Umumî Kısım, İstanbul Üniversitesi Yayımları, 3. Basım, İstanbul 1953.

USLU, Cennet: İnsan Haklarının Felsefi Temelleri: Doğal Hukuk ve Doğal Haklar, Hacettepe Üniversitesi Sosyal Bilimler Enstitüsü, Yayımlanmamış Doktora Tezi, 2007.

UYGUN, Oktay: Hukuk Teorileri, 2. Bask1, On İki Levha Kitabevi, İstanbul Haziran 2020.

VAHAPOĞLU BINDESEN, Zehra: Arthur Schopenhauer'da Kötülük Problemi ve Mutluluğun İmkânı, Atatürk Üniversitesi Sosyal Bilimler Enstitüsü, Yayımlanmamış Doktora Tezi, Erzurum, 2019.

WOODS, David: "Seriously bored: Schopenhauer on solitary confinement", British Journal for the History of Philosophy, 27(5), 2019, s.959-978. 